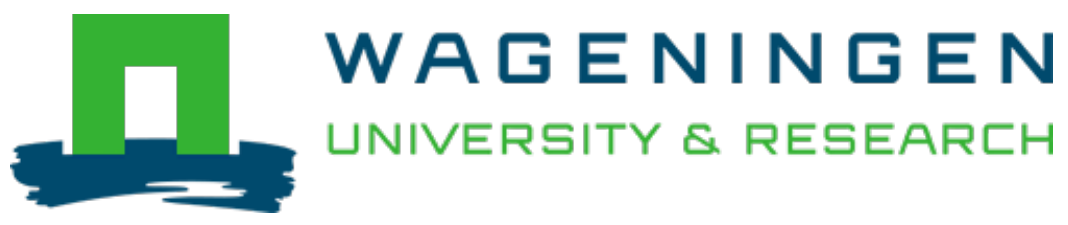

\title{
Representative Agricultural Pathways: : A Multi-Scale Foresight Process to Support Transformation and Resilience of Farming Systems
}

Handbook of Climate Change and Agroecosystems

Valdivia, R.O.; Homann-Kee Tui, S.; Antle, J.M.; Subash, Nataraja; Singh, Harbir et al

https://doi.org/10.1142/9781786348791_0003

This publication is made publicly available in the institutional repository of Wageningen University and Research, under the terms of article $25 \mathrm{fa}$ of the Dutch Copyright Act, also known as the Amendment Taverne. This has been done with explicit consent by the author.

Article 25 fa states that the author of a short scientific work funded either wholly or partially by Dutch public funds is entitled to make that work publicly available for no consideration following a reasonable period of time after the work was first published, provided that clear reference is made to the source of the first publication of the work.

This publication is distributed under The Association of Universities in the Netherlands (VSNU) 'Article $25 \mathrm{fa}$ implementation' project. In this project research outputs of researchers employed by Dutch Universities that comply with the legal requirements of Article $25 \mathrm{fa}$ of the Dutch Copyright Act are distributed online and free of cost or other barriers in institutional repositories. Research outputs are distributed six months after their first online publication in the original published version and with proper attribution to the source of the original publication.

You are permitted to download and use the publication for personal purposes. All rights remain with the author(s) and / or copyright owner(s) of this work. Any use of the publication or parts of it other than authorised under article $25 \mathrm{fa}$ of the Dutch Copyright act is prohibited. Wageningen University \& Research and the author(s) of this publication shall not be held responsible or liable for any damages resulting from your (re)use of this publication.

For questions regarding the public availability of this publication please contact openscience.library@wur.nl 


\title{
Chapter 3
}

\section{Representative Agricultural Pathways: A Multi-Scale Foresight Process to Support Transformation and Resilience of Farming Systems}

\author{
Roberto O. Valdivia*, Sabine Homann-Kee Tui ${ }^{\dagger}$, John M. Antle*, Nataraja Subash", \\ Harbir Singh ${ }^{\S}$, Swamikannu Nedumaran ${ }^{\mathbb{I}}$, Ibrahima Hathie" \\ Muhammad Ashfaq**, Javaria Nasir** , Geethalakshmi Vellingiri ${ }^{\dagger \dagger}$, \\ Lakshmanan Arunachalam $^{\dagger \dagger}$, Lieven Claessens ${ }^{\star \dagger}$, Dilys S. MacCarthy ${ }^{\S}$, Samuel Adiku ${ }^{\text {IIII }}$, \\ Wiltrud Durand $^{\|\|}$, Caleb Dickson*** ${ }^{*}$ Hermine Mitter ${ }^{\dagger \dagger \dagger}$, and \\ Martin Schönhart ${ }^{\dagger \dagger}$ \\ * Oregon State University, Corvallis, OR, USA \\ ${ }^{\dagger}$ International Crops Research Institute for the Semi-arid Tropics (ICRISAT), \\ Bulawayo, Zimbabwe \\ \$CAR-Indian Institute of Farming Systems Research, Meerut, \\ Uttar Pradesh, India \\ $\S$ Indian Agricultural Research Institute (ICAR), Pusa, New Delhi, India \\ II International Crops Research Institute for the Semi-arid Tropics (ICRISAT), \\ Hyderabad, Telangana, India \\ "Initiative Prospective Agricole et Rurale (IPAR), Dakar, Senegal \\ ** Institute of Agricultural and Resource Economics, University of Agriculture, \\ Faisalabad, Pakistan \\ ${ }^{\dagger \dagger}$ Tamil Nadu Agricultural University, Coimbatore, Tamil Nadu, India \\ * International Institute of Tropical Agriculture (IITA), Arusha, Tanzania \\ Tanzania Wageningen University \& Research, Wageningen, \\ the Netherlands \\ $\S$ Soil and Irrigation Research Centre, University of Ghana, Accra, Ghana \\ III University of Ghana, Accra, Ghana \\ "\| Bureau for Food and Agricultural Policy (BFAP), Pretoria, South Africa \\ *** Oregon Parks and Recreation Department, Salem, Oregon, USA \\ ${ }^{\dagger \dagger}$ University of Natural Resources and Life Sciences, Vienna, Austria
}




\section{Introduction}

Agriculture and food systems face complex challenges: population growth, crop and livestock yield gaps, environmental degradation, climate change and variability, social conflicts, and economic stressors. There is a need for long-term informed decision-making to provide a base for future generations. Research approaches and investments aim to provide more accurate information, while accounting for these complexities, to accelerate transformation to sustainability. One major challenge is that conventional climate change assessments assume the same socio-economic conditions in the future as today. An approach is required that can characterize plausible future socio-economic conditions and the state of agricultural production under those conditions. Integrating improved technology with governance and institutional development, in a way that is gender-sensitive, is critical for attaining sustainable and resilient agriculture and food systems. A stronger integration of science and stakeholder-based knowledge will enable priority setting and support decision-making processes effectively, guided by a joint strategy development.

New science-based approaches are being developed that support information for decision-making, forging the collaboration between scientists and stakeholders. The Agricultural Model Intercomparison and Improvement Project (AgMIP) has developed methods that guide scientists and stakeholders to design agricultural development pathways, supported by quantitative and qualitative analysis of pathway outcomes. The process enables scientists and stakeholders to guide decisions for immediate use, and set priorities for more conducive conditions for a sustainable future. Science can thereby support countries to decide and plan on climate change actions based on a sound understanding of vulnerability and growth potential, and prepare for adaptation with links to other sectors.

Representative Agricultural Pathways (RAPs) (Valdivia et al., 2015) have been developed as a part of AgMIP's Regional Integrated Assessment (RIA) method for modeling and projecting agricultural systems in the present and future (Antle et al., 2015). RAPs deliver scenarios about possible future states of the world in which climate change might happen. Once established and quantified, they allow for model-based projections of future bio-physical, technological, institutional, and socio-economic conditions - critical parameters for assessing agricultural systems in any climate - that cannot be tested in a real-world context.

The RAP setup involves an iterative process executed among scientists and stakeholders of different expertise. This ensures the RAPs formation taps multiple sources of knowledge, as well as informed dialogue about drivers and interactions among parameters and how they contribute in shaping future worlds. RAPs storylines are translated and quantified into model parameters, such as farm and herd size, prices and cost of production. RAPs, together with global economic model data on crop 
yields and price trends, can be used to explore impacts of adaptation options, which scientists and stakeholders consider relevant and useful.

The RAPs process starts with creating a robust baseline. During the first phase of the DFID-funded project, the AgMIP Regional Research Team (RRT) engagement in Sub-Saharan Africa and South Asia produced a series of RAPs for the particular farming systems following a "Business as Usual" pathway. In the second DFIDfunded phase, the RRTs developed additional sets of pathways, including a future that is driven by sustainability goals (e.g., so-called "Green RAP"), and a future that is driven by economic growth without considering sustainability (e.g., so-called "Grey RAP").

The RRTs in India and Zimbabwe advanced the RAPs concept to link the farming systems-specific RAPs with national level RAPs through stakeholder engagement across scales. Extending the RAPs approach from sub-regional to national scales allowed us to bring systems-specific issues to a national level. It also allowed us to jointly identify inconsistencies and gaps in policy formulation and implementation at the different scales.

Inspired by AgMIP development of RAPs in Sub-Saharan Africa and South Asia and by initial steps in the European MACSUR project, a set of pathways for European agriculture (the Eur-Agri-SSPs) have been developed by researchers from European universities and research organizations. We include the process and major outcomes towards Eur-Agri-SSPs with a discussion of lessons learned in this contribution.

\section{Conceptual Framework for Socio-Economic Scenarios}

The AgMIP Phase II scenario development followed the approach developed in Phase I (Valdivia et al., 2015) to link site or country-specific drivers and global socio-economic pathways (SSPs) associated with a range of global emission scenarios (RCPs). This recognizes that local actions and their impacts will be affected by global drivers and their impacts. Local narratives were then combined with price and productivity trends from global economic models. The overall goal of this process was to develop scenarios that could be used to support adaptation strategies (i.e., policy or technology changes) under changing socio-economic conditions.

\section{Plausible emission and socio-economic scenarios (RCPs and SSPS)}

The global emission and socio-economic scenarios provided global projections that were used as inputs to the regional projections defined in the RAPs. The AgMIP global economics team ran multiple scenarios contrasting global SSPs with plausible levels of emissions (RCPs) as shown in Table 1 (Wiebe et al., 2015). 
Table 1. Scenario definition used by global economics team.

\begin{tabular}{|c|c|c|c|c|c|}
\hline Scenario & SSP & $\begin{array}{l}\text { Radiative } \\
\text { Forcing }\end{array}$ & GCM & $\begin{array}{l}\text { Trade } \\
\text { Policy }\end{array}$ & $\begin{array}{c}\text { Economic } \\
\text { Model }\end{array}$ \\
\hline 1.0 & \multirow{5}{*}{ SSP 1} & \multirow[t]{5}{*}{ No change } & none & \multirow{4}{*}{ No change } & \multirow{4}{*}{$\begin{array}{c}\text { ENVISAGE, FARM, } \\
\text { IMPACT, MAGNET, } \\
\text { MAgPIE }\end{array}$} \\
\hline 1.1 & & & HadGEM & & \\
\hline 1.2 & & & IPSL & & \\
\hline 1.3 & & & MIROC & & \\
\hline 1.4 & & & HadGEM & Liberalized & ENV, FAR, MGN, MGP \\
\hline 2.0 & \multirow{4}{*}{ SSP 2} & No change & none & \multirow{4}{*}{ No change } & \multirow{4}{*}{$\begin{array}{c}\text { ENVISAGE, FARM, } \\
\text { IMPACT, MAGNET, } \\
\text { MAgPIE }\end{array}$} \\
\hline 2.1 & & & HadGEM & & \\
\hline 2.2 & & RCP 6.0 & IPSL & & \\
\hline 2.3 & & & MIROC & & \\
\hline 3.0 & \multirow{5}{*}{ SSP 3} & No change & none & \multirow{4}{*}{ No change } & \multirow{4}{*}{$\begin{array}{c}\text { ENVISAGE, FARM, } \\
\text { IMPACT, MAGNET, } \\
\text { MAgPIE }\end{array}$} \\
\hline 3.1 & & & HadGEM & & \\
\hline 3.2 & & RCP 8.5 & IPSL & & \\
\hline 3.3 & & & MIROC & & \\
\hline 3.4 & & & HadGEM & Restricted & ENV, FAR, MGN, MGP \\
\hline
\end{tabular}

Source: Wiebe et al., 2015.

The AgMIP RRTs used climate data from RCP 4.5 (low emission) linked to SSP1 (low challenge, sustainability) and RCP 8.5 (high emission) linked to SSP 3 (high challenges, fragmentation) to simulate the impacts of climate change on crop yields and livestock performance (see also AgMIP Handbook v7, 2017). Productivity and commodity price trends for these scenarios were obtained from outputs from the IMPACT global economic model.

\section{Regional Representative Agricultural Pathways (RAPs)}

RAPs provide qualitative and quantitative information to characterize the state of a future world under which a particular farming system might operate. Thus, boundaries and characteristics of current farming systems must be clear, to develop realistic estimates of agricultural and socio-economic parameters and interrelations. They also need to represent farming systems that are meaningful for a country, so that the recommendations can be brought to scale. The RAPs parameters provide inputs to the AgMIP RIA.

Based on the definitions of SSPs and RAPs described in Valdivia et al. (2015) and the data and information from the combination of RCPs and SSPs mentioned above, RRTs developed the following RAPs in AgMIP Phase II (see Figure 1):

RAP 4: "Sustainable low growth (Green RAP)"

- Low economic growth and associated economic and policy features

- High sustainability and associated environmental performance and policies 


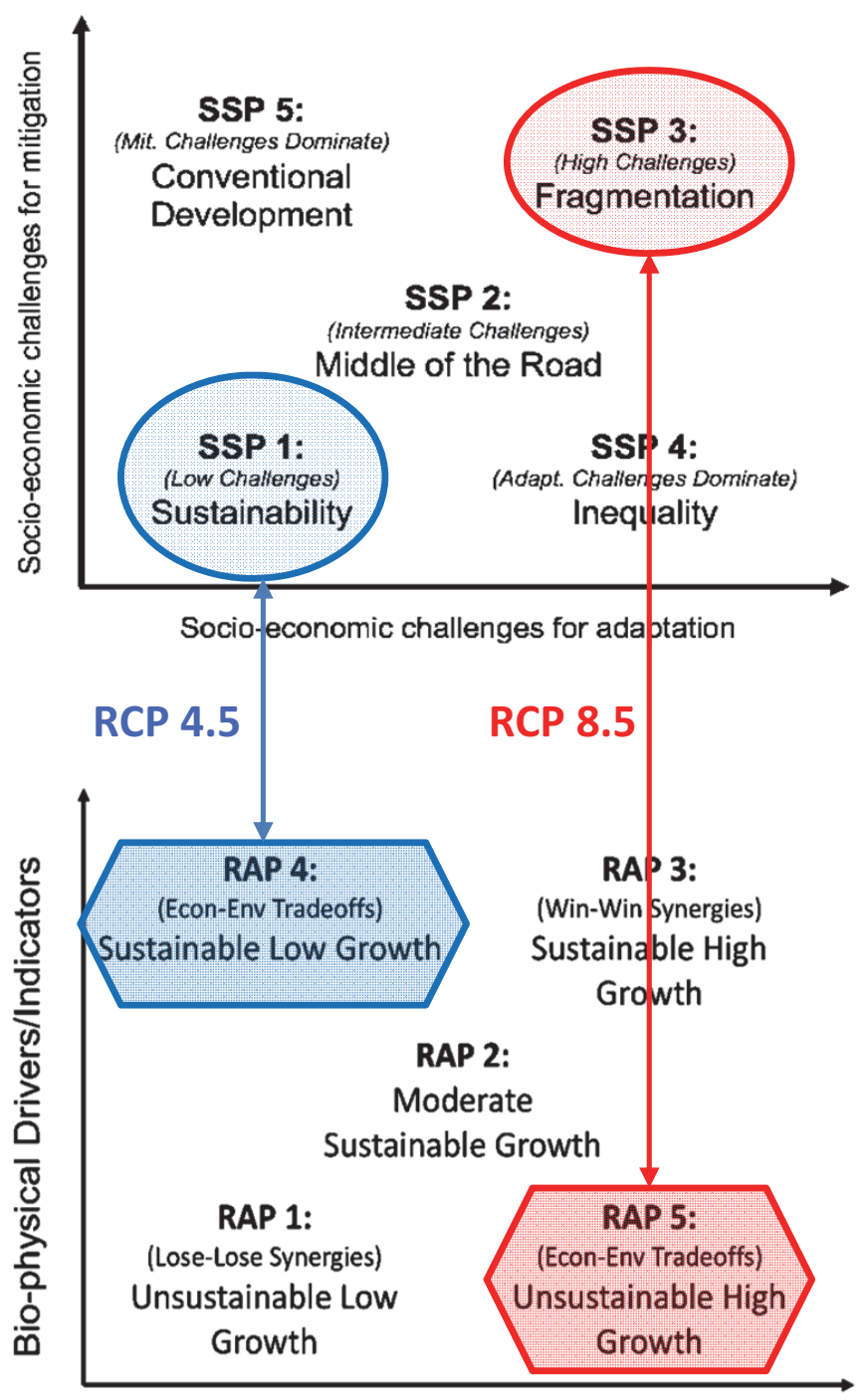

\section{Economic and Social Drivers/Indicators}

Fig. 1. Future socio-economic scenarios: Linking SSPs, RCPs, and RAPs for AgMIP RRT Phase II. Source: SSPs matrix obtained from O'Neill et al., 2017. RAPs matrix obtained from Valdivia et al., 2015.

- Low challenges to adaptation (as defined in SSP1)

- Low challenges to mitigation (as defined in SSP1)

RAP 5: "Unsustainable high growth (Grey RAP)"

- High economic growth and associated economic and policy features

- Low sustainability and associated environmental performance and policies 
- High challenges to adaptation (as defined in SSP3)

- High challenges to mitigation (as defined in SSP3)

\section{Using yield and price trends}

Given the high level of uncertainty with regards to price trends (Wiebe et al., 2015), and the need to capture the range of possible output prices in the future, RRTs conducted sensitivity analyses on the output price assumptions by contrasting highprice and low-price assumptions. These high and low prices were based on the range of prices obtained from the global model projections for the relevant commodities in each region. The price assumptions were defined in relation to each RAP and SSP combination, while also considering if climate has induced changes in prices or not.

The procedures to estimate a set of yields and price trends and the sensitivity analysis are summarized as follows.

\section{Estimating yield trends}

Step 1: Estimated change in yield without climate change: Output data from IMPACT and the corresponding scenario were used to calculate the compounded yield growth factor $\Gamma$ between current and future periods without climate change.

Example: For Kenya's rainfed maize, the 2005 yield is $2407 \mathrm{~kg} / \mathrm{ha}$ and the 2050 yield is $4887 \mathrm{~kg} / \mathrm{ha}$, so the estimated maize yield growth trend factor is:

$$
\Gamma=4887 / 2407=2.03 \text {. }
$$

\section{Step 2: Estimated projected future yield:}

Example: Suppose maize yield is $1800 \mathrm{~kg} / \mathrm{ha}$, then the future projected yield without climate change is:

$$
1800 \times \Gamma=1800 \times 2.03=3655 \mathrm{~kg} / \mathrm{ha} .
$$

\section{Estimating price trends}

We define $\phi_{h}^{k}$ as the output price trend, where $k=L$ for low output price assumption, and $k=H$ for high output price assumptions; $h$ is 1 or 2 , representing the no climate change and with climate change prices, respectively.

Step 3: The future crop prices with and without climate change were estimated using the price trend $\phi_{k}^{h}$ for all commodities at all sites and scenarios (SSP1 and SSP3), which in turn, were obtained from producer price data from the IMPACT model. 
Example: For Kenya's rainfed maize, the 2005 producer price is $42.03 \mathrm{USD} /$ tonne and the 2050 price is $92.79 \mathrm{USD} /$ tonne, which means the price trend with no climate change is $\phi_{1}^{H}=2.21$ or $221 \%$. Note that, for the high price assumption, we have used the price trends estimated from IMPACT. Then, suppose the current period maize price in the region is 25 Kenyan Shillings per kg of maize. Then the price for 2050 is:

$$
25 \times 2.21=55.25 \mathrm{Ksh} / \mathrm{kg} .
$$

Step 4: Future prices were used to estimate model parameters for the base system and the alternative system as described in the AgMIP Handbook, Appendix 2 (Handbook v7, 2017).

\section{Price sensitivity analysis}

A sensitivity analysis to the price assumptions using a "high price range" and a "low price range" was conducted using the following guidelines:

\section{Notation:}

$P_{t h}^{k}=$ Price of a commodity,

$h=1$ no CC (i.e., system 1 ),

$h=2$ with CC (i.e., system 2),

$t=c$, current; $t=f$, future,

$k=H$ : high price,

$k=L$ : low price,

$\phi_{h}^{k}=$ price trend factor

A. High price range: For this case, the teams used the IMPACT data as described above to estimate the future prices with and without climate change:

$$
\begin{aligned}
& P_{f 1}^{H}=P_{c} \phi_{1}^{H} \text { future price without climate change, high price range } \\
& P_{f 2}^{H}=P_{c} \phi_{2}^{H} \text { future price with climate change, high price range }
\end{aligned}
$$

B. Low price range: For the lower price range it was assumed that:

a. Current price $=$ future price with no $\mathrm{CC}$

b. Deviation of prices with climate change with respect to no climate change prices is the same for high and low prices (see Fig. 2).

Following the trajectories shown in Fig. 2, the relative price or the deviation range from the no climate change to the with climate change case for the high price assumption was estimated as:

$$
r_{p}=P_{f 2}^{H} / P_{f 1}^{H}
$$




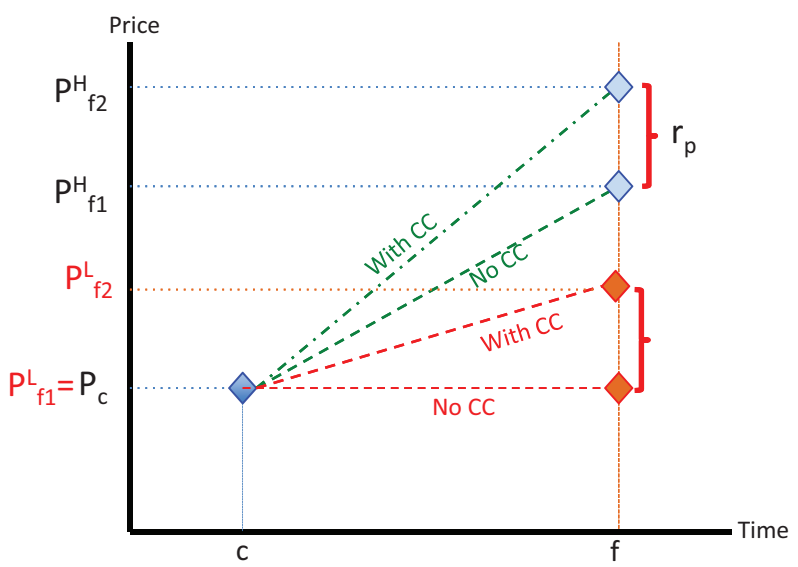

Fig. 2. Sensitivity analysis of future output prices.

Source: Valdivia and Antle, 2016, RAPs Protocols AgMIP Phase II.

Then, as per assumption $\mathrm{b}$ above:

$P_{f 1}^{L}=P_{c}$ future price with no climate change, then we can estimate

$P_{f 2}^{L}=P_{c} r_{p}$ future price with climate change

\section{Implementation of RAPs in the Regional Integrated Assessments}

RAPS and adaptation packages are part of the RIA, a protocol-based approach that provides credible information on context-specific systems states, vulnerability, welfare levels, under current conditions and possible futures. Stakeholders combined with a team of scientists identify key issues and questions that are relevant for a specific agricultural system and region, and the results are replicable and directly relevant to the stakeholders involved (Fig. 3).

These are the specific objectives:

1. Define farming systems, key drivers, and their interrelations to support the design of plausible future development scenarios (RAPs) for the region.

2. Identify and co-develop adaptation packages specific to the farming systems being studied. Stakeholders and scientists were challenged to think about ways to re-design farming systems under current and future conditions.

3. Capacitate stakeholders on the RIA process and outputs.

\section{RAPs Developed for RIAs by AgMIP RRTs}

The AgMIP RRTs and stakeholders, using RAP 2 ("Baseline"), drafted two contrasting future worlds for their particular farming systems by establishing measurable 


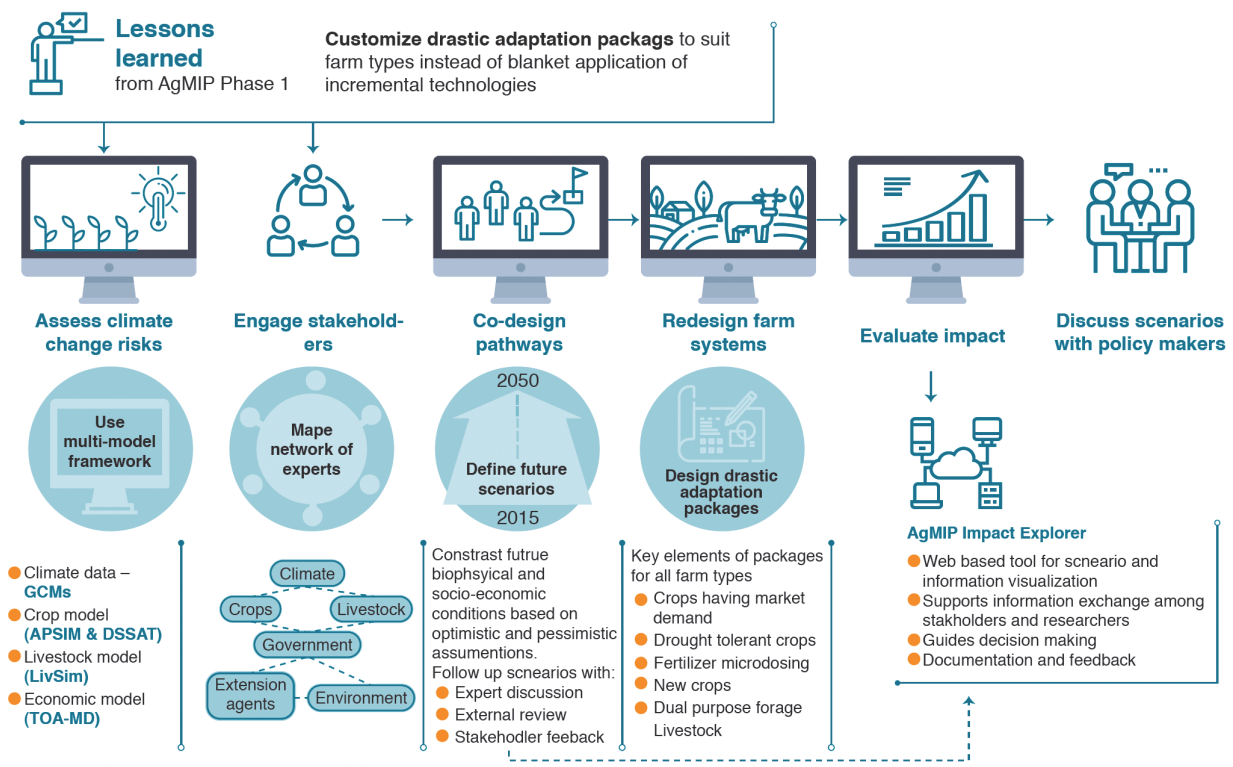

Fig. 3. The AgMIP Regional Integrated Assessment of Climate Change Impact, Vulnerability, and Adaptation of Agricultural Systems and the process of co-designing RAPs and Adaptation packages. Source: Valdivia et al., 2019, adapted from ICRISAT, 2016.

outcomes expected with investment in sustainable development vs. fast economic growth. These scenarios represent farming systems and production methods (i.e., the technologies) for particular farming communities, in their physical environments (i.e., the climate) and the economic, policy, and social environments in which they operate (i.e., the socio-economic setting). The following scenarios illustrate the diversity of drivers and relations and how they shape the future of farming systems in different contexts.

\section{Zimbabwe}

In both futures, productivity increased substantially. The main action for climate change adaptation would be the use of heat- and drought-tolerant crop varieties. Heat- and drought-tolerant varieties would benefit more under a sustainable future. The poorest would benefit more in relative terms, though they largely remained extremely poor. Vulnerability would be higher with fast economic growth, farmers with large herds would be stricken by feed gaps. Investment in sustainable development was less risky and better for the poor.

Green Pathway. Investing in a sustainable future had clear advantages: inclusive markets and access to information that creates incentives for all farmers to invest, 
farmers setting more land in value, diversifying and intensifying crops, and increasing herd size.

Grey Pathway. The fast-economic growth future was crafted after the experiences of the past in Southern Africa. The better-off, market-oriented (MO) farmers would expand and invest, whereas the poor would rely on off-farm income, often becoming suppliers of cheap labor.

With regards to agricultural policies, the RAPs process in Zimbabwe created confidence in the urgency to prioritize the following:

- Support the production of fodder: Highlighting the importance of fodder for higher level policymakers created recognition of climate change risks for those with many animals. Access to fodder can mitigate the effects of drought and climate change; also, it has become a component of irrigation policy.

- Support improved access to forage seed: Establish linkages in crop and livestock departments so they can make joint decisions. Help decision makers in each department understand the importance of forage seed for farming systems' integration through feed and soil amendment. Therefore, promoting and scaling access to forage seed to larger areas should be prioritized.

- Support the revitalization of legumes, especially for very poor households: The release of new varieties can fuel national seed systems for food, feed, soil, income, women empowerment, and climate change resilience.

- Support confidence in promoting small grains: Focus on previously neglected crops with strong responses to management improvement; uptake spurred by investments in crop improvement, agronomy, post-harvest, processing technologies, and market development.

\section{India - Indo-Gangetic Basin}

India is moving towards achieving the Sustainable Development Goals (SDGs) of eradicating poverty and hunger. The key pillars for success are public and private investments in $\mathrm{R} \& \mathrm{D}$, technological innovations, and policies aimed at effective natural resource management, which helps sustaining agricultural growth under adverse climatic conditions. However, population increase and rise in food demand result in intensive and unsustainable use of natural resources without considering negative environmental effects. Thus, two possible future scenarios were developed:

Green Pathway. Restructuring of traditional support policies (e.g., subsidies, MSPs) helps sustainable increase in crop and livestock productivity. Investments in infrastructure, markets, and human capacity building slows population growth rate and improves household income distribution. 
Grey Pathway. Agricultural productivity increases due to new technology and agricultural intensification efforts. However, agricultural policies are ineffective to deal with demographic, ecological and developmental problems. These issues coupled with unstable market conditions, due to domestic and international conflicts, lead to social inequality and weak institutions for collective action, which exposes the sector to adverse climate impacts.

\section{Lessons learned}

- Divergence in understanding of the problem by various stakeholders and local and national levels.

- Farmers' concern was not only declining farm profitability but also government apathy for addressing their problems (fertilizer prices, seed, labor shortage, higher wages, transportation cost, and inadequate marketing facilities).

- It was very difficult to focus the discussion around major bio-physical, socioeconomic, and technology variables.

- Participants, particularly farmers, expressed their opinion on a lot of other issues not directly related to the farm sector.

- To gather all the desired information about the relevant variables from such a diverse group of stakeholders, needs more time, and mutual understanding for adhering to the steps in RAPs development process.

\section{India - Andhra Pradesh, South India}

Consistent efforts by past and present governments, international conventions (like Voluntary Guidelines on the Responsible Governance of Tenure of land, fisheries, and forests (VGGT)), and efforts to develop institutional capacities of communities for collective action are likely to improve security of land tenure and facilitate moderately improved access to irrigation water and agri-food value chains for smallholder farmers. Improvements in rural and agricultural infrastructure and services, while soil health and groundwater availability and quality are expected to decline, result in small improvements in agricultural productivity.

Green Pathway. Andhra Pradesh continues in the progressive path of successfully implementing the National Mission on Sustainable Agriculture (NMSA) coupled with reforms in key sectors such as energy, land, and water that are crucial for sustainable intensification in agriculture. The holistic approach that includes economic and ecological objectives will enhance the productivity of all sectors and the incomes of the farm households. Improved access to financial services through SelfHelp Groups (SHGs) and collective actions through farmer producer companies and cooperatives will drive inclusive growth. Ecosystem services-based governance of 
natural resources will ensure environmental sustainability. Investments on public health, education, skill development, and rural infrastructure will slow population growth and improve household welfare.

Grey Pathway. Increased population growth, growing demand for food and fuel, coupled with low investment in resource-efficient and high-yielding technologies will lead to over-exploitation of land and water resources. There will be low adoption of productivity-enhancing technologies due to limited access to financial services. Slow and ineffective reform processes in energy, water, and land tenure lead to highly inequitable distribution of resources. Inadequate infrastructure and low skill levels in rural areas lead to high post-harvest losses and lower opportunities for non-farm employment, which further reduces household income. Low investment in health and education in rural areas leads to migration of unskilled labor to urban areas, increasing poverty and nutrition insecurity.

\section{India - Tamil Nadu, South India}

The effects of climate change are felt throughout the state of Tamil Nadu. The weather is highly irregular with the rising temperature trends, and the intensity and frequency of droughts and floods that affect the poor and most vulnerable are growing. Tamil Nadu's government is working very hard to counter the effects of climate change through many programs, including the development and implementation of a State action plan on climate change. Government policy also promotes climateresilient farming practices by offering incentives and developing people's capacity to cope with extreme climatic conditions.

Green Pathway. Tamil Nadu implements the programs under NMSA. The state is also adopting cleaner and low-carbon technologies, including renewable energy. Mass tree planting is promoted to increase the green cover. Water harvesting structures have been created to increase the water availability in the state. Soil and water conservation measures are practiced for improving agricultural productivity.

Grey Pathway. In Tamil Nadu, the agricultural sector is highly impacted by fluctuation in prices for the harvested produces. Moreover, conflict for water is increasing as the state does not have major catchment areas, making crop cultivation highly uncertain. Technological interventions have improved the productivity of the crops, however, due to indiscriminate use of fertilizers and pesticides, greenhouse gas concentration is increasing in the atmosphere. Water pollution due to leather and dyeing industries is yet another issue of great concern to agriculture. Fragmentation of farm holdings also increases the small and marginal farm holdings leading to increased vulnerability. 


\section{Pakistan}

Food security (FS) and poverty reduction are the main challenges for the developing economies of South Asia. Future agricultural systems will be different due to radical technological advancements.

Green Pathway. Government prioritizes the agricultural sector to achieve food security and sustainable development, with increased public investment in research, technology, infrastructure, and extension services. Support in the form of agricultural finance, insurance, improved seed, and information and technology transfer will support farming systems. Imports of food grains will be liberalized. Educational and health investments will reduce population growth.

Grey Pathway. Production increases will be through technological advancements, improved cultivars, and mechanized farming, increasing cropping intensity. Subsidies will be on farm machinery, agricultural inputs, and outputs due to high input and output prices. Intensification of agriculture will negatively affect the natural ecosystem. Public policies prioritize increasing agricultural growth to feed the masses and take advantage of trade opportunities at the expense of resource deterioration.

\section{Kenya}

In both futures, productivity increases substantially, largely due to (partly) implementation of agricultural interventions and policies outlined in Vision 2030 for Kenya focusing on meeting the Millennium Development Goals (MDGs) and the SDGs.

Green Pathway. Increased investment in technologies that are environmentally friendly has helped the country achieve a sustainable pathway. However, economic growth has slowed as the main investments are focused on public services such as health, education, and clean energy. Policy changes and infrastructure improvements facilitate the development of markets and availability of agricultural inputs, leading to higher farm incomes. Farms become more diversified and less dependent on maize; there is increased crop-livestock integration and off-farm income. Moreover, household sizes are smaller while farm sizes are larger.

Grey Pathway. The government has an aggressive policy to promote the industry and services sector and there is low investment in sustainable agricultural policies. Import barriers are in place and lead to increases in prices of imported goods, including mineral fertilizers. Low investment in health and education contributes to an increase in inequality. High population growth increases the pressure on agricultural land with the consequences of unsustainable agricultural intensification and negative environmental effects. Moreover, farms become smaller in some areas, while consolidation occurs in other areas. 
The RAPs process created confidence in the following trends, disaggregated for different agro-ecologies (or maize potential zones, MPZs) in Kenya:

\section{Green Path}

- High and medium MPZs: increased use of mineral fertilizers, manure (produced on-farm), and improved maize varieties. Productivity is also improved by extension, education, and information available to farmers. These changes are accompanied by decreases in fertilizer prices, increases in seed prices, increases in labor wages, and increases in mechanization costs. There are also a number of changes in livestock production due to government investment in infrastructure for the livestock and dairy sectors. Households increase their herd sizes (including more improved breeds) and implement improved management practices, such as using more concentrates for feed. This leads to higher milk yields and higher production costs. Moreover, due to market development, milk prices increase.

- Low MPZ: Milk-selling farms decrease their reliance on maize and focus more on milk production. The proportion of land area currently allocated to maize is decreased in order to increase the area of Napier grass and pastures. On the remaining maize land, these households institute similar improved management practices as those discussed above.

\section{Grey Path}

- High and medium MPZs: farms increase their proportion of maize area compared to the current systems. Maize yields increase due to similar management improvements as in RAP 4, except production occurs with more adverse environmental outcomes. For example, farms use less organic fertilizer and less soil conservation techniques, which results in soil degradation. Similar to farm size, average herd sizes do not change compared to current systems, but there is increased variation as some farms increase their herds and others decrease. Milk yields improve due to improved management and breeding, which leads to increased production costs as well. Moreover, milk price increases for similar reasons as RAP 4, but to a lesser extent. There is a lower degree of crop-livestock integration than in RAP 4, as well. Households do not use the outputs from livestock activities (e.g., manure) as productive inputs in crop activities (and vice versa) to the same extent as in RAP 4.

- Low MPZs: Milk-selling farms allocate land to Napier grass and pastures, but to a lesser degree than in RAP 4. Maize production systems and milk production systems are similar to RAP 4, but with increased soil degradation and less croplivestock integration, resulting in lower manure use. In addition, milk prices do not increase to the same degree as RAP 4, due to lower market development. 


\section{South Africa}

South African agriculture is influenced by multiple exogenous factors, with the three most important being domestic macro-economic conditions, policy uncertainty, and international market dynamics, which all contribute significantly to high levels of uncertainty. Despite initially improved sentiments surrounding changes in government, reform has been slow and South Africa's economy continues to face multiple structural challenges. Thus, following a period of prolonged growth, the combination of variable climatic conditions and macro-economic fluctuations have created an exceptionally volatile environment for South African agriculture, which is anticipated to be exacerbated by climate change.

The interaction with the stakeholders highlighted that there were certain factors within the local sphere where the farmers had a great deal of influence, e.g., precision farming, conservation agriculture, crop rotation, crop type, and choice of cultivar, while there were, however, many more factors the farmers have very little power over which are in the hands of policymakers, politicians, and the broader community to make contributions, e.g., greenhouse gas mitigation legislation, trade tariffs, minimum wages, exchange rates, land reform, and crime/theft, to name but a few.

Green Pathway. This path is the so-called "Pap, Vleis, and Gravy" (i.e., "porridge, meat, and gravy") path, which is characterized by a low-carbon green economy with sustainable growth and it mainly focuses on conservation agriculture.

Grey Pathway. This path, the so-called "Skorokoro" scenario, meaning worn and ragged beyond its years, is one in which we have the case of the "tragedy of the commons" where everyone can use, but all will share in the abuse of, the ecosystem.

The RAPs process leads to the following findings:

- Global prices will still govern profitability: Profitability levels might be higher under the "Skorokoro" (Grey Pathway) scenario; however, yield variability is less under the "Pap, Vleis, and Gravy" (Green Pathway) scenario, which can be mainly attributed to the projected pricing structures for the commodities associated with each of these projections by global economic models.

- Policy certainty must be one of government's highest priorities: Commercial farmers are more interested in policy adaptations than in bio-physical adaptations and these will have to be addressed to ensure continued plantings of the staple crops, especially in the light of national FS.

- Irrigation is not an option to mitigate the effect of climate change: Assuming that enough water is available, expanding irrigation as a strategy to mitigate the 
effects of climate change in the Free State will be a poor choice as an adaptation strategy, as modeling indicates that both yields and profits are projected to decrease marginally.

- Support crop breeding and research: Over 60\% of farmers in the Free State are projected to adopt proposed adaptation packages. Investment into the breeding of heat- and drought-tolerant cultivars and research into conservation agriculture and good crop husbandry is therefore important.

\section{Senegal - Nioro}

In the "sustainable future" (Green Pathway) as well as the "fossil fuel development" (Grey Pathway) scenario, climate change will impact cereal yields negatively, while peanut productivity will benefit from climate change due to $\mathrm{CO}_{2}$ fertilization effects on peanuts. Overall, due to the importance of peanuts in the households, climate change would have a positive impact on Nioro farmers' livelihoods, under high price scenarios. Under low prices, climate change would have a negative impact on Nioro farmers' livelihoods in most cases.

In both price scenarios, adoption rates are higher for the sustainable future. Also, simulation results show that more farmers tend to adopt the adaptation package (heattolerant varieties) when they produce under unfavorable price conditions. Under the sustainable futures, the adaptation package yields greater outcomes, such as higher returns to farmers or lower poverty rates.

Green Pathway. Inclusive approaches in public policies are implemented alongside significant development of community initiatives and greater accountability of grassroots organizations. Good agro-ecological practices are mainstreamed, including through appropriate training of local actors and curriculum development in schools and training institutes. Fertilizer subsidies are increased slightly, while the use of organic fertilizer is encouraged.

Herd sizes decrease a bit, partly due to land fragmentation. But livestock productivity improves, as a result of improved feeding and animal health programs. Agro-ecological practices and sustainable land management contribute to a restoration and a gradual improvement of soil fertility in particular with better integration of crop-livestock production systems. The use of water storage technologies and better management induce increased availability and accessibility to water.

Decentralization policies are fully implemented in a context of improved human and social capital. The development of infrastructure, greater access to ICTs, and the process of urbanization put some stress on labor availability, in particular for on-farm activities, while ongoing social and economic processes generate household segmentation along with greater labor demand for off-farm income. 
Grey Pathway. Population growth and rapid urbanization lead policymakers to further develop infrastructure and rapidly raise agricultural productivity. The agricultural sector is a policy priority and must respond quickly to increased demand, particularly from urban dwellers. Input subsidies, development of road networks, and the revitalization of the peanut basin are key interventions.

These policies and interventions are fulfilled without proper application of good and environmentally friendly agricultural practices, thus contributing to soil degradation and unsustainable use of water resources. Herd sizes and livestock productivity rise as a result of improved political support to the sector, better health protection programs, greater urban demand, and the determination of pastoralists to seize these market opportunities.

The development of the digital economy, mechanization of agriculture, and a strong energy demand exert a powerful influence on rural activities. Household size decreases along with fragmented farms. Stronger and better road networks increase employment opportunities outside agriculture.

\section{Ghana - Navrongo}

Both Representative Agriculture Pathways will result in increased productivity, but in a more sustainable manner under the Green Pathway. On the one hand, all indicators under bio-physical, institutional, and technological categories will increase, but in varied magnitudes, under both RAPs; on the other hand, most of the indicators under the socio-economic category would decrease under the Grey Pathway.

Green Pathway. Environmental concerns are at the heart of Ghana's development pathway. This translates to an emphasis on soil conservation and the increased use of manure, resulting in part from greater herd size. Despite this inclination for sustainability, fertilizer use is likely to increase. Policymakers design ambitious policies that provide subsidies to both organic and chemical fertilizers. They also pay greater attention to agricultural research and policies that support sustainable agriculture. Extension services are also improved, tapping on various new tools and providing tailored knowledge and information to farmers.

Profound structural changes affect families and farms. Education and urbanization induce people to migrate and family size to decrease progressively. At the same time, the consensus around sustainability means that family-based agricultural systems are required to cope with the labor-intensive nature of these systems. However, as more land is available, mechanization receives full support from policymakers who are eager to witness productivity gains, both on crops and livestock, but demand a sustained use of these resources. Livestock plays a key role, not only for its contribution to land restoration, but also its source of revenues that are essential to the livelihoods of most farmers. 
Grey Pathway. Modernization and intensification of agriculture are the focus of Ghana's development pathway, with the aim to produce sufficient food locally, to meet the increasing population demands. Due to high imports of rice, meat, and poultry products, shortfalls in maize production, and the persistent and widening gap between consumption and domestic production, it is the desire of the government to reduce these production deficits significantly. As a result, policies are set for a rapid agricultural growth and output which would be achieved via increased use of inputs such as fertilizers, supplementary irrigation, increased machinery use that would increase production acreages, and labor productivity among others. Animal productivity is expected to increase due to more capital input, improved disease control, as well as due to the high income groups becoming attracted to commercial agriculture. Interviews with various stakeholders point towards significant deterioration of the soil quality and its resilience due to intensive use of heavy machinery and minimum conservation measures. It is expected that the continuous introduction of mechanization would displace agricultural labor demand, leading to rural-urban drift, slight increase in off-farm occupations, and long-term reduction in household sizes.

The development of these two RAPs lead to the following conclusions. Under the Grey Pathway, adoption must be equally balanced by intensive soil conservation strategies. The peculiar low inherent organic matter content and low structural stability of tropical soils would require the adoption of less heavy but effective machinery, such as power tillers, instead of the promotion of the heavier type of tractors. Engineering structures that reduce runoff leading to reduced erosion must be a priority as part of the modernization drive. Agrochemical use must also be regulated, as the use of chemicals is expected to increase. Addressing this challenge will require intensive farmer education and enhanced extension services.

In the case of the Green Pathway, it has to be noted that though it is environmentally friendly and sustainable in the long run, measures to fill the short-term production shortfalls have to be put in place to alleviate any initial food shortages. Where chemicals are to be used as part of no till systems, farmer training would be required.

Policies for a rapid agricultural growth and output would be achieved through:

- Increased use of inputs such as fertilizers with the introduction of subsidies to enable more smallholders to be able to afford and increase use of the same;

- Improved pricing and infrastructure to optimize benefits from produce and reduce post-harvest losses respectively;

- Another important policy is increased education and improved extension services to help promote good agronomic practices among farmers and thus, increase productivity;

- Supplementary irrigation to offset climate change effects; 
- Increased use of appropriate machinery that would increase production acreages, labor productivity among others.

\section{RAPs across Scales: Lessons from Initial Applications}

Guiding and influencing future worlds requires supportive policy and institutional frameworks across scales and landscapes. The common observation of low adoption rates, despite high potential for technologies, requires us asking why changes are not being implemented, and goes back to persisting institutional barriers. A more comprehensive analysis about policies and institutions and consistency between policy formulation and their implementation are required. In countries with complex political division like India or Zimbabwe, national and local level policies might be formulated and implemented in different ways.

The RAPs approach allows us to compare national narratives and drivers with those at the regional, district, or local level and verify their consistency. Agricultural policies are usually issued at national level. These policies inform state level conditions and investments, and these, in turn, influence the local level conditions (Fig. 4). Within a country, it is also possible that state-level conditions differ across

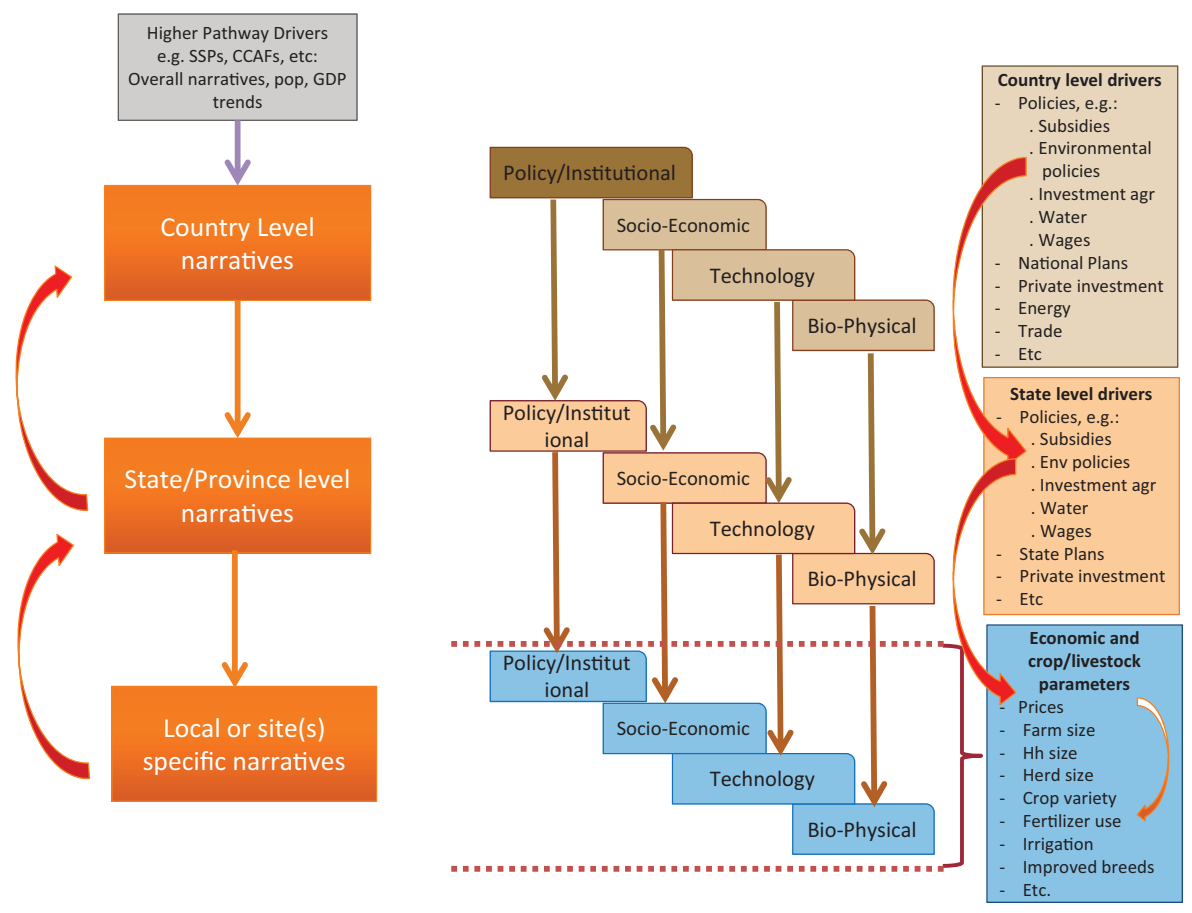

Fig. 4. Scope of RAPs across scales. 
the landscape, with implications for the local level conditions. Local level drivers explain much of the dynamics at play, under the framework of national policies and the extent to which they are being implemented. For developing sustainable adaptation options and pathways, it is hence important to understand the higher-level drivers (e.g., policies) and how consistently they are being implemented across the sites. In this context, the RRTs of India and Zimbabwe developed and implemented protocols to develop national level RAPs using their local-specific pathways as starting points. These processes that included engagement of national-level stakeholders are described as follows.

\section{India - Multiple sites informing national RAPS}

\section{National RAP process}

The need to verify consistency of national policies and conditions came up when comparing results from local level assessments. Consistency is crucial for the process of developing and testing adaptation options across the different sites. National and state level RAPs were developed and implemented in AgMIP RRT Phase II (see Box 1 and Fig. 5). The framework, followed to engage with stakeholders, is described in Fig. 5.
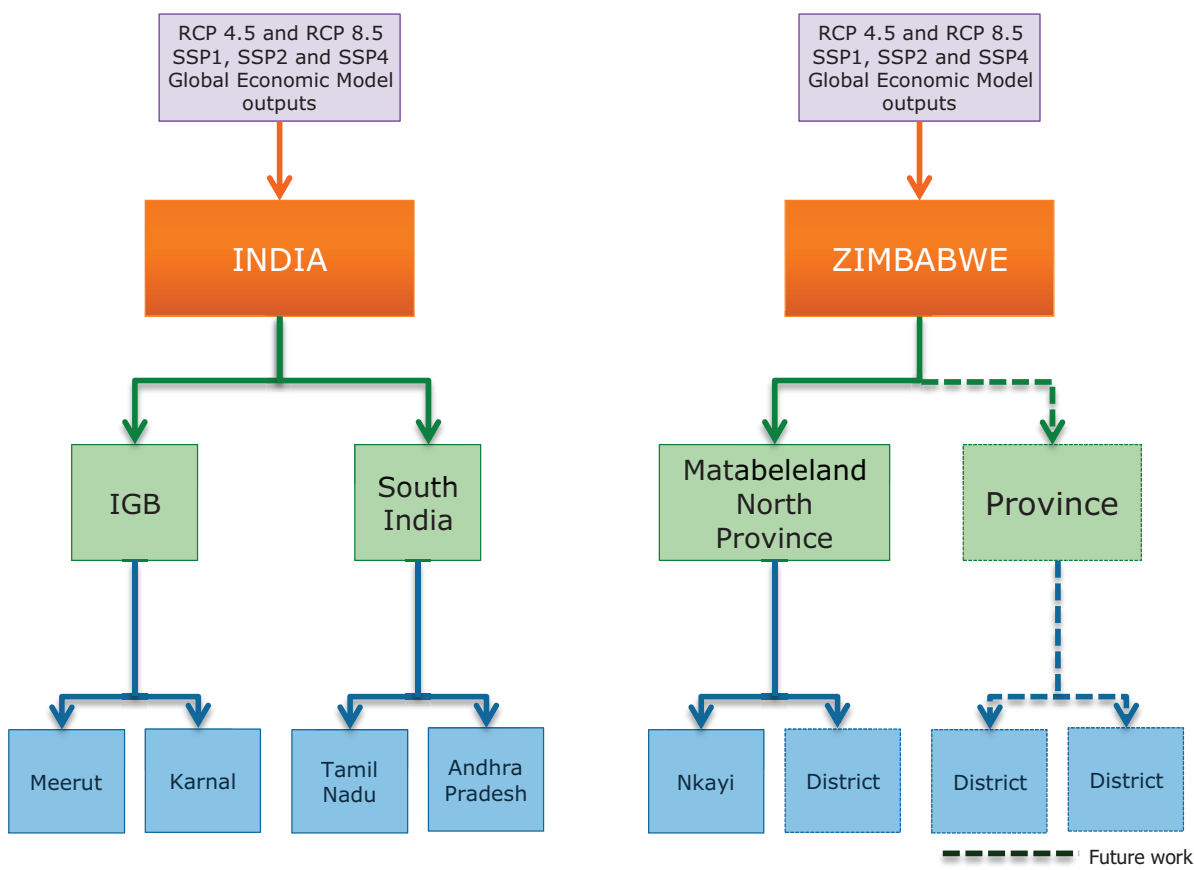

Fig. 5. National RAPs for India and Zimbabwe. 


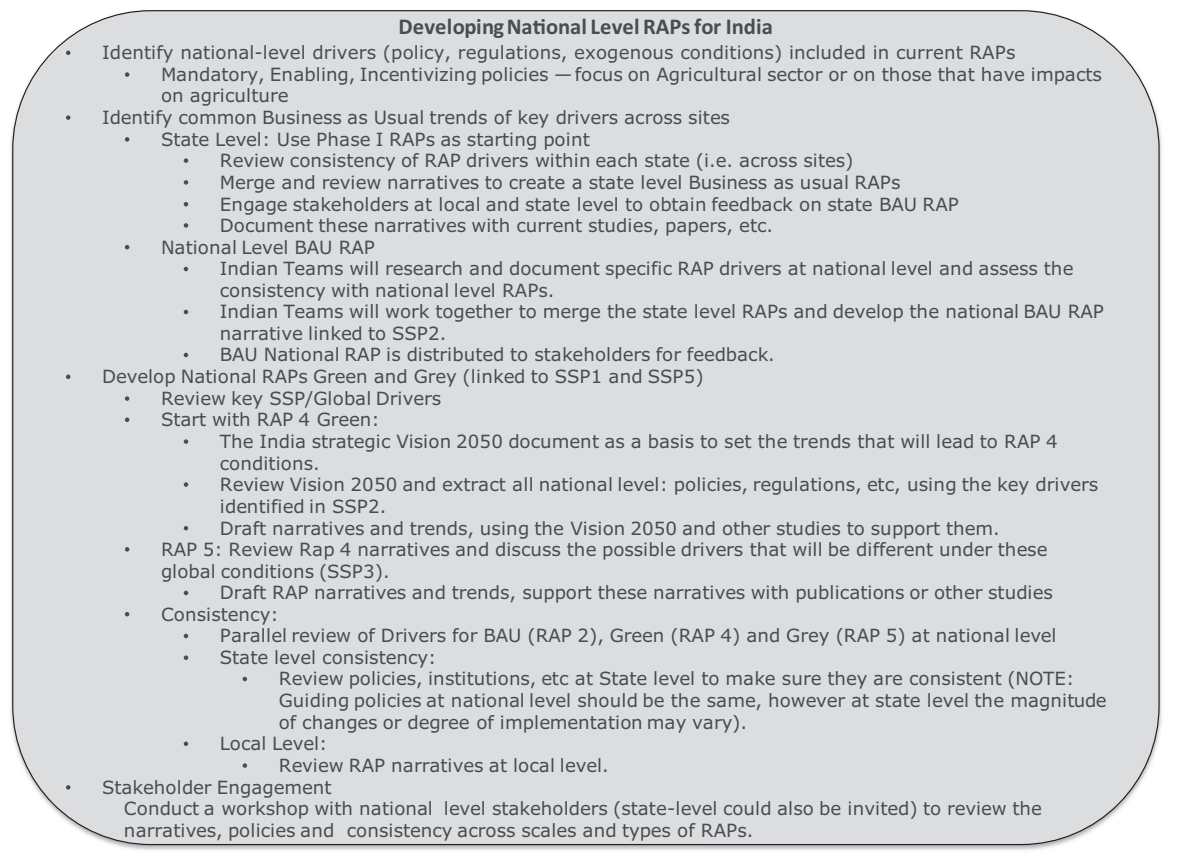

Box 1. Steps to develop national-level RAPs for India.

\section{The process}

RAPs process was initiated and implemented by involving site-specific research and developmental institutions from the state and national agricultural research system, and also farmers, line departments, and developmental organizations.

This process was upscaled at regional and national levels, which ensured collective participation and feedback from all the stakeholders.

At local level, more weight was given to farmers' inputs and feedback on different growth scenarios, while at the national level, consultation with experts from national and international (CG institutions) research systems provided more scientific rigor to the two development pathways visualized for Indian agriculture.

- The IGB Team initiated the RAPs development process with a brainstorming meeting of the stakeholders organized at PDFSR Modipuram (Meerut), India in July 2013.

- Prior to this meeting, the team discussed and prepared local RAPs trends in consultation with fellow researchers from the national agricultural research system.

- The brainstorming meeting saw participation of the farmers, agricultural development officials, senior faculty from the agricultural university and scientists from the agricultural and environmental sciences field. 
- Prior information was provided to all the participants about the usefulness of RAPs and the objectives of the stakeholders' consultation.

- After an overview of AgMIP project, steps in RAPs development were explained to the participants, followed by detailed discussion on the future scenario of farming in the region.

- The event was widely covered by the local media.

\section{National RAP Narratives}

RAP 2: Business as usual. India follows the current trends in relation to population and economy growth. Government continues with agricultural policies as is the usual practice. Industries (energy and fertilizer) face issues to modernize and innovate. Government reduces subsidies to increase industries' earnings with the hope they can innovate and use modern technology. However, there is little change in market infrastructure and input prices due to the continued dependence on imports to satisfy domestic demand. International regulations and trade lead to continued MSPs for major water-intensive crops. Policy on land tenure increases land fragmentation due to inheritance policies, thus reducing average farm size. At the same time, non-farm activities cause a decrease on agricultural labor availability. Government promotes and facilitates the use of new improved crop varieties, however, yield increases are limited due to low soil productivity and the low use of mineral and organic fertilizers. Increase in productivity is higher in regions where investments on irrigation and value-chains have been promoted by private sector rained by further decline in soil health and groundwater availability and quality.

\section{RAP 4: "Green India" moving along the sustainable development pathway.} India's efforts in sustaining economic growth, poverty alleviation, and improving food security contributed to the success of achieving the Sustainable Development Goals and to continue the sustainability pathway. The key pillars for this success are based on public and private investments for $R \& D$ and technological innovations that take into account improving environmental conditions and reducing social inequalities. Policies oriented to promote sustainable natural resource management practices, land use policies along with investments in infrastructure, markets, extension services, human capacity (e.g., improved education and health services) lead to restructuring of traditional support programs (e.g., subsidies, MSPs) and use those resources for programs that help increase farm productivity (increase crop and livestock yields) sustainably. Government investment on public health and education slows population growth rate and improves household income distribution.

RAP 5: "Gray India" moving along the degradation pathway. India's continued economic growth places the country as one of the largest economies in the world 


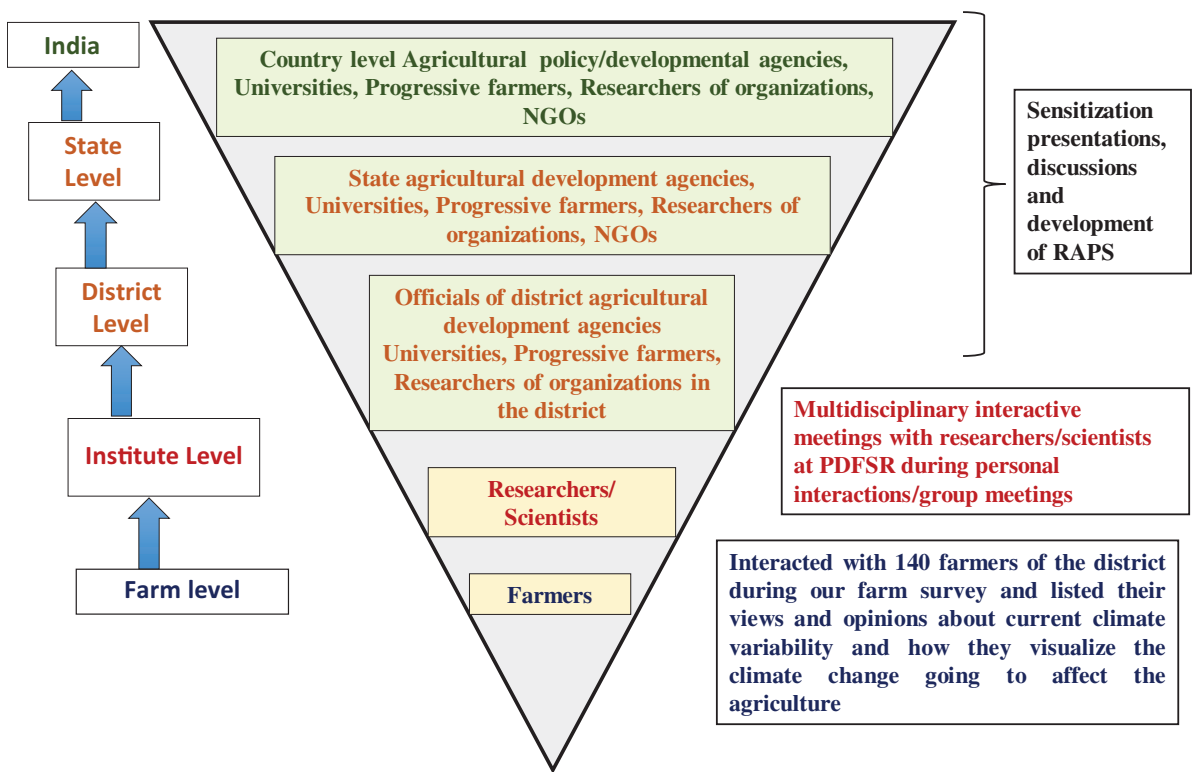

Fig. 6. Development of National RAPs in India: Framework to engage stakeholders across multiple scales.

(Fig. 6). However, increased population and demand for food leads to establishment of policies aimed at reducing food insecurity but without consideration of negative effects on the environment (e.g., soil and water quality). Unsustainable agricultural practices (e.g., continuous mono cropping) and land fragmentation cause conflicts over the use of natural resources (e.g., water). Government policies are unable to deal with demographic, ecological, and developmental problems. Low investment on health and education in rural areas and new off-farm opportunities due to development of new industries shift labor out of agriculture. Unstable market conditions due to domestic and international conflicts prompt the government to increase protection programs for farmers (e.g., MSP). Agricultural productivity has increased due to new crop varieties, but land degradation and other environmental issues have started to cause little response to improved varieties and other new technologies. Social inequality has increased due to ineffective reforms for security of land tenure and weak institutions for collective action.

\section{Stakeholder Feedback}

The first brainstorming meeting was followed up by a meeting with higher level research managers and policy planners (mid-term workshop). It emerged that:

- Though there is District Contingency Plan \& mid-term correction, there is no formal action plan for climate change adaptation. 
- Farm science centers (632) exist for information delivery, and private sector-led mobile advisory services project adverse weather conditions.

- The available technologies more than double production potential, if locationspecific adaptation strategies are to be followed.

- More sites need to be covered for location-specific RAPs for comprehensive Integrated Assessment of IGB region, which has huge diversity.

- Network of research institutes working on climate change issues in IGB must be developed.

- There are no perfect RAPs - hence several RAPs may be developed for each region.

- Emphasis should be on the farming system approach to manage climate change and minimize risk.

- Wider participation of policymakers in RAPs development process will have more influence in decision making for adaptation to climate change.

- Climate change requires a long-term strategy - hence AgMIP RIAs should be taken up for longer duration.

\section{Some reflections from stakeholders:}

Dr. Alok K. Sikka, DDG (NRM), ICAR

- Ensemble of GCMs should be explored to get single value of climate change impact on agricultural production systems.

- More adaptation packages need to be tested.

\section{Prof. Akhtar Haseeb, Vice-Chancellor, NDUAT, Faizabad}

- AgMIP scenario analysis should provide projection for near future (year 2030) also.

- The University will provide all-out support for such (climate change projection) type of research.

\section{Dr. K.K. Singh, Director (Agromet), IMD, Ministry of Earth Sciences}

- Local level climate forecast and advisory and its dissemination through automation is the need of the hour.

\section{National-level RAPs workshop}

A national-level RAPs workshop was carried out in New Delhi with the participation of key national and state level stakeholders, scientists, and AgMIP's team members. The overarching goal of the national level workshop was to validate the national 
level Green and Grey Representative Agricultural Pathways and finalize the narratives and indicators/drivers which project long-term agricultural changes in India by incorporating the inputs from experts/subject-matter specialists. The idea of a national RAPs meeting was introduced by the IGB team during the AgMIP Phase-I proposing an inverted pyramid approach for stakeholders' engagement, as shown in Fig. 3. The main focus at the national level workshop was:

- Cross-cutting themes focusing on uncertainty, aggregation over scales, and representative agricultural pathways consistent with SSP and RCP;

- Model inter-comparisons and improvements under different scenarios;

- Inter-disciplinary team of climate, crop modelers, and economic modeling supported by information technologies for regional, global, and crop-specific assessments;

- Capacity building and decision-making for vulnerability assessment and adaptation strategies.

\section{Outcomes for stakeholders}

- Knowledge was gained on the process and outcomes of RAPs, as all the stakeholders were unaware of RAPs when the day started.

- Stakeholders opined that it was good opportunity to integrate their needs/ experiences with the AgMIP research for mutual benefit.

- They got the opportunity to be part of RAPs science community/modeling group that would keep them in the information loop in the future.

- Experiences and exchange of ideas during the meeting may sow the seed for future research.

\section{Outcomes for AgMIP}

- AgMIP gained visibility among decision makers and top-level scientific community.

- RAPs scenario for "Green India" and "Grey India" got vetted, and the process for finalizing the RAPs was initiated.

- New insights were gained for more focused modeling simulations and assessments.

- The need for AgMIP India was expressed unanimously by the stakeholders.

\section{Overall findings}

- The national RAPs consultation provided an opportunity to integrate stakeholders' needs with AgMIP research for mutual benefit. 


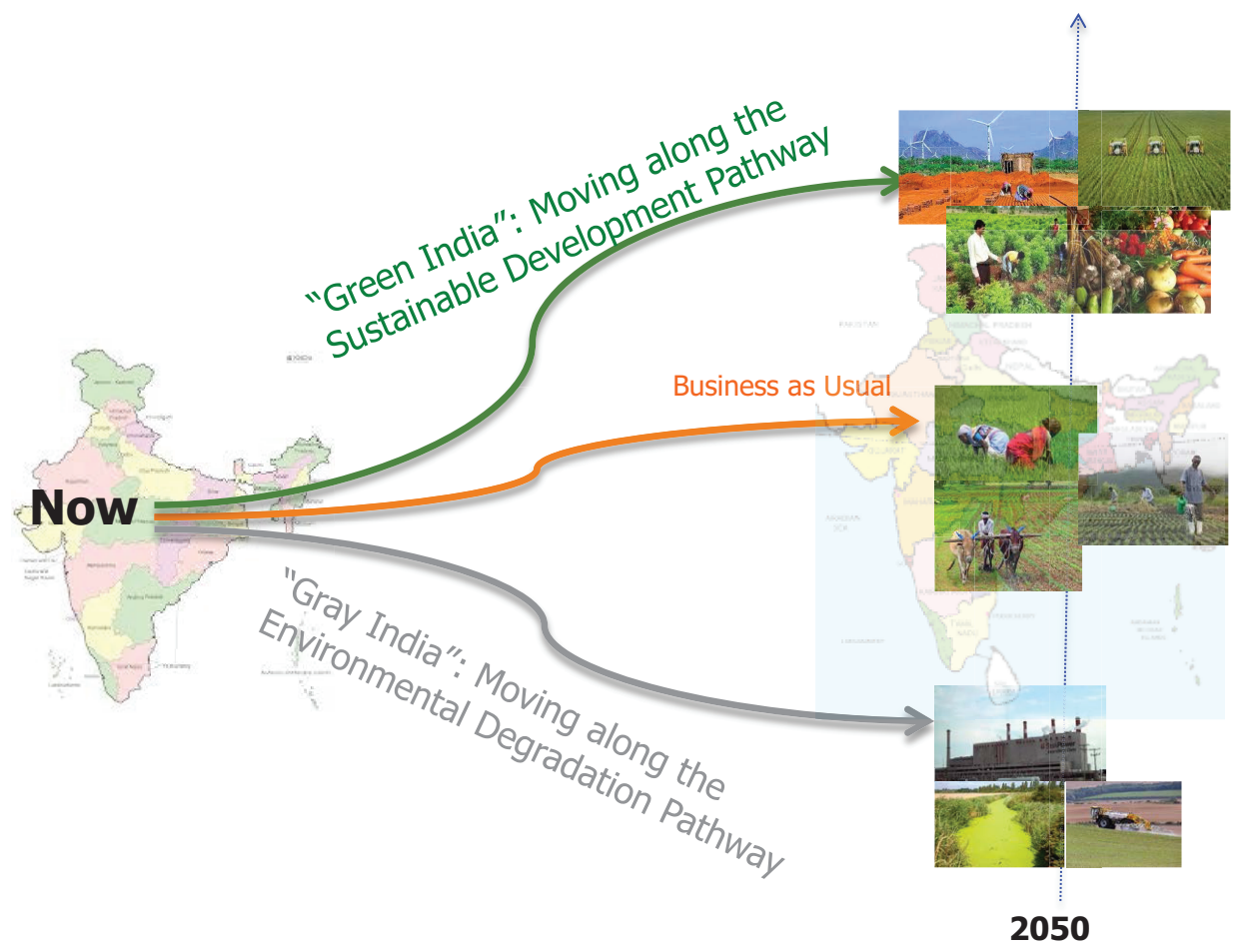

Fig. 7. National Representative Agricultural Pathways for India.

- The stakeholders were eager to be part of RAPs science community/modeling group that would keep them in the information loop in future, and experiences gained may sow the seed for future research.

- AgMIP gained more visibility among decision makers and top scientific community. RAPs for Green India and Grey India got vetted by the stakeholders (see Fig. 7).

- New insights gained from this workshop helped in more focused modeling work, and finally, the AgMIP India concept got a thumbs up from the stakeholders.

\section{Zimbabwe - National RAPs for crop livestock farming systems}

National RAP process

The Crop Livestock Intensification Project (CLIP) was implemented in Nkayi district, for representing drylands in Zimbabwe, which cover about a third of Zimbabwe, and for which integration of crops and livestock was recognized as a trajectory. 


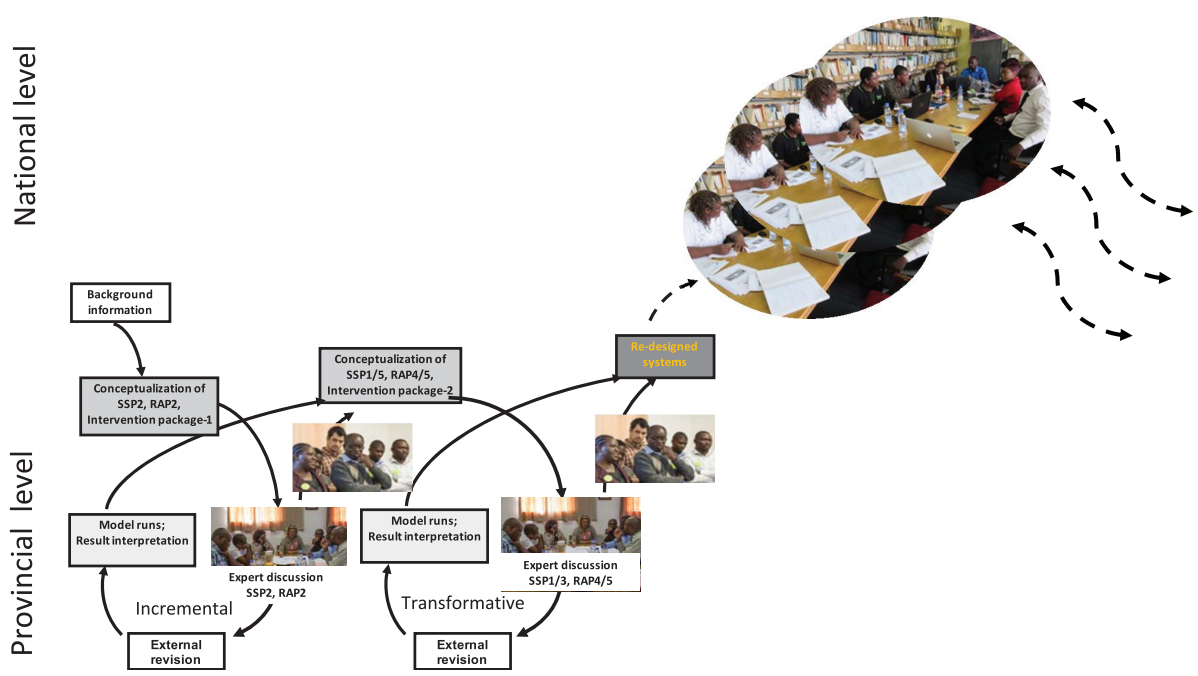

Fig. 8. AgMIP-CLIP iterative process at provincial and national levels.

The RAP process had started at provincial level with regional analysis, on climate change impacts assessments (see Fig. 8). The approach and results were scaled up to national level dialogue, providing solid information on policies and other trends, while at the same time verifying consistency between local to national level institutional and policy frameworks. Participants at the national RAP workshop included national and sub-national representatives on crops, livestock, economics, environment, climate, and gender, from government departments, academia, and UNDP.

These were the steps for developing the national RAPs:

1. Drafting the baseline: The RRT along with a few national government representatives had drafted national RAP 2 (BAU), adjusted from provincial level assessments and screening government policies and background literature, followed by an AgMIP internal revision.

2. National level preparatory meeting: national and provincial stakeholders had used the draft national BAU RAP as baseline to develop draft national Green and Grey RAPs.

3. National RAP workshop: national and provincial stakeholders initially discussed approaches and tools, efficiency, and gaps in policy decision-making process in Zimbabwe. They then revised the three RAPs, and initiated the discussion on usefulness of RAPs to inform national decision processes.

4. Revision of both provincial and national level RAPs, with feedback from the AgMIP's internal revision processes.

5. Creation of additional RAPs, considering socio-political dynamics. 


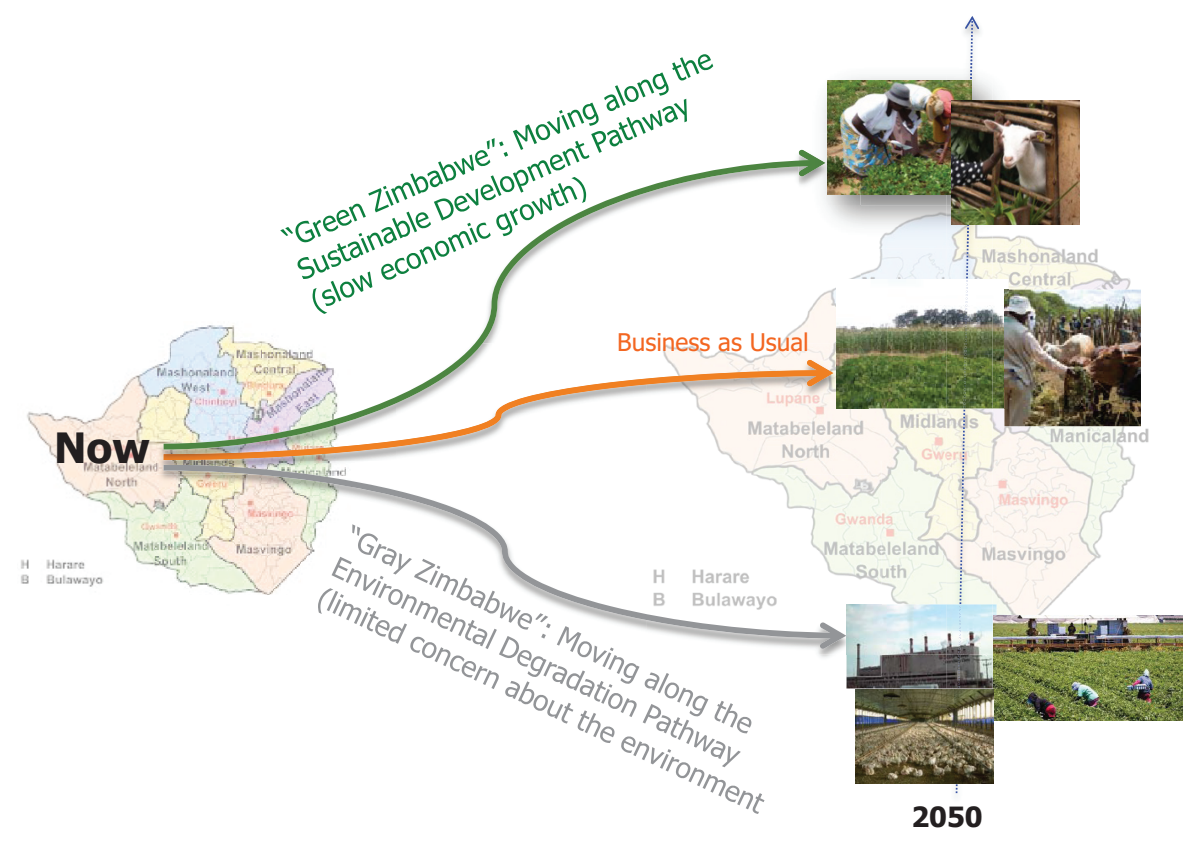

Fig. 9. National Representative Agricultural Pathways for Zimbabwe.

\section{National RAP narratives for Zimbabwe}

RAP 2: Business As Usual, Zimbabwe slowly emerges out of crisis. Zimbabwe's agricultural policies aim to achieve food and nutrition security, and reduce rural poverty through mid-term-oriented increased and market-oriented crop and livestock production (Fig. 9). Policy implementation will however remain fragmented, due to slow recovery from the economic crisis and weak institutions. Interventions are driven by objectives to address food and income deficits and provide safety net assistance. Economic constraints will slow down investments and longer term production improvements. Improving land tenure security will provide incentives for the private sector in some areas and for some commodities. Efforts to revitalize market infrastructure and organization and greater support to extension services for technology uptake will slightly increase the contribution of agriculture to the Gross Domestic Product (GDP). Liberal trade policies with trade fluctuations due to recurrent droughts will reduce price growth. Environmental degradation will still be on the increase, despite greater emphasis on environmentally sound productivityenhancing technologies. Limited employment opportunities in urban areas curtail rural-urban migration.

RAP 4: Green Zimbabwe, Sustainable development. Zimbabwe's agricultural policies are towards food and nutrition security and inclusive economic 
development, through longer term socially, economically, and environmentally sustainable transitions. There will be proactive collaboration and self-organization among private sector, research and development, farmer unions, and civil society. The public sector will support institutional development, policy implementation, and oversight. Emphasis will be on promoting market-based solutions that improve market access and work for all farmers, and sustainable intensification (rainfed and irrigation) raising productivity, production, and market surplus, while promoting risk-minimizing technologies.

Policies enabling infrastructure development, land tenure security, human capacity, along with R\&D investment in scaling technical innovations and delivery services will make farming more cost-effective and attractive. Intensification will be through large-scale diversification of food and cash crops, integration of multiple uses of crops and livestock, synergies between inorganic and organic soil fertility amendments, and on-farm livestock feed production. Government support for equitable access to human health and education will raise the average rural life expectancy, while slowing down the population growth rate. It will favor cultural diversity and women's role in agriculture, reducing labor burdens and easing women's access to input and output markets. Economic development will, however, be slow, and provide only limited options for alternative income generation, curtailing rural-urban migration.

The group agreed on a name that represents the Green RAP best for them: Greener pastures (Huchi Nemukaka, land of plenty, milk and honey) (see Fig. 10). This scenario was seen as promoting inclusive growth and sustainable livelihoods in the agricultural sector, ecosystems that respect agriculture.

RAP 5: Grey Zimbabwe, Fast economic development. Zimbabwe's agricultural policies target fast economic growth through trade within the Southern Africa regional network. Government plays a strong role in controlling the economic pull by the more advanced economies to develop their comparative economic advantages within the region. The agricultural economy will be driven by objectives to commercialize the farming sector, using intensified farming methods for quick achievements of food security and cash income, with large areas of land under staple and cash crops. Intensification will be through specialization, with high use of exotic crops and breeds, inorganic fertilizers, commercial livestock feeds, and mechanized production processes. With a tendency to monoculture, levels of pest and disease control will be high. Public and private investments will support the intensification processes, and agro-industries and agricultural delivery systems will push the dissemination of improved technologies, inputs, and information. High economic growth rates in agriculture will however not last, due to unsustainable practices and unfairness in market processes. 


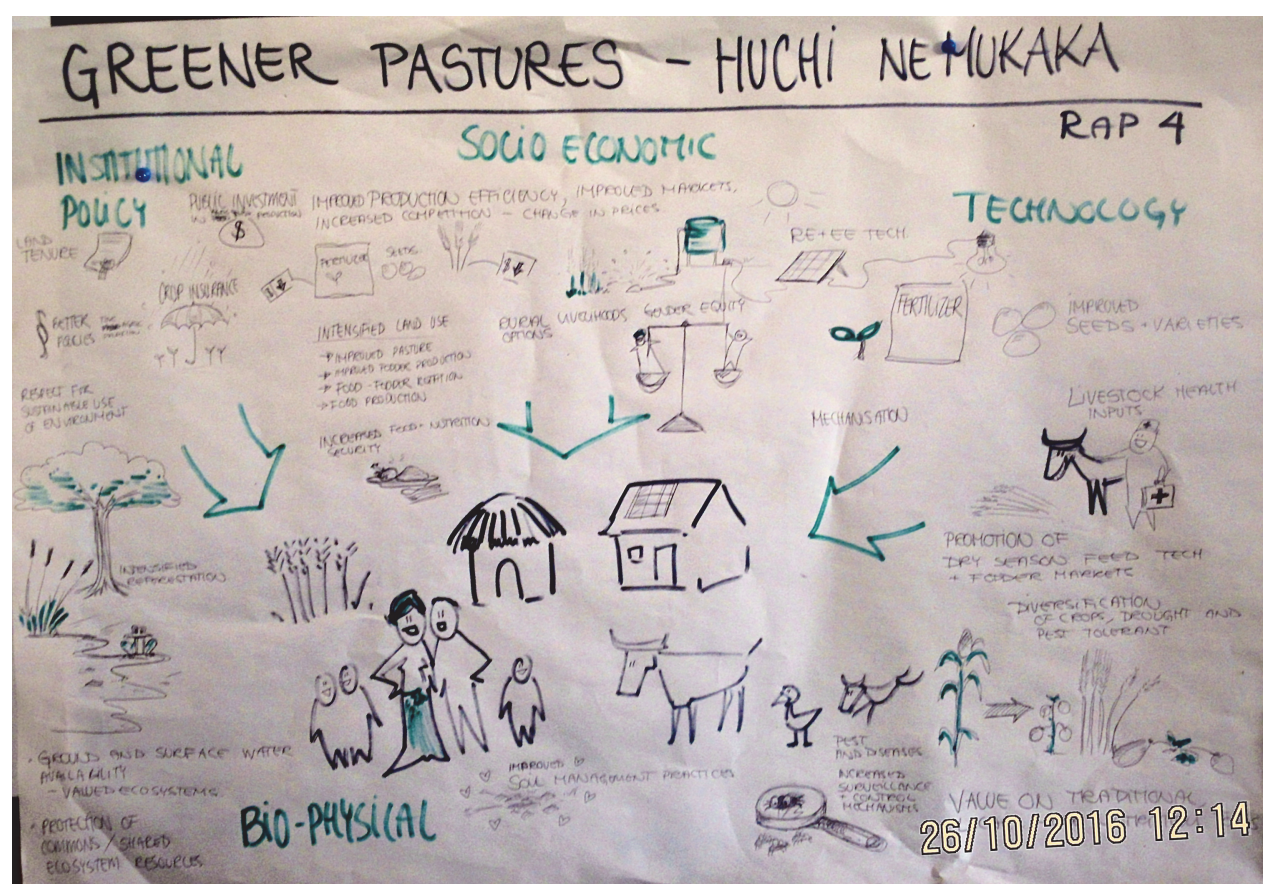

Fig. 10. Zimbabwe's Green RAP: Greener pastures - Huchi Nemukaka.

Environmental services will be driven by the motivation to ensure market flows; rampant deforestation and clearing of land will cause degradation in large parts of the country. Pollution levels will increase, with risks of food contamination and health hazards. Disregard of social standards and individualization in rural development processes will eventually lead to growing inequality among rural populations. Higher potential rural areas will be managed by commercializing farmers, while large parts of the population will be driven to practice agriculture in marginal rural areas and aggravate resource degradation.

In this future world, fewer of those more MO farmers, with cattle and in a better position to intensify, will expand and intensify agricultural production, through mechanization and increasing the use of local labor. The number of poor will increase, people who still depend on agriculture for sustaining FS, and hence maintain a small share in agriculture, while also engaging more in off-farm activities than farming themselves, thus, becoming a reduced labor force. This future lacks empowerment support for rural communities and is male dominated. Urban and agricultural industries will provide employment opportunities for the poor, enhancing migration out of agriculture. Life expectancy of the average rural population will decline. 


\section{Examples of how the national RAP process supported initiatives}

As the RAPs were designed to match with context-specific conditions and trends, so are the RRT's lessons generated from engaging with stakeholders in this process.

\section{Zimbabwe}

- RAPs design and impact assessment itself was feasible with a small budget, through integration with ongoing projects.

- Trust, confidence, and continuity was established with the Climate Change Management Department in the Ministry of Environment, Water and Climate. A key officer was co-opted into the AgMIP IE panel, and has been advising on the co-design of national scenarios.

- The department linked the AgMIP-CLIP team to networks, programs, and dialogues at national levels in Zimbabwe, on climate change and SDGs.

- Links were established to ongoing climate change adaptation initiatives to inform how climate change adaptation options can be brought to scale, tested, verified, in such way that they respond not only to climate but also the future state of other socio-economic and environmental challenges.

- The department requested more government staff to be capacitated in climate modeling and scenarios development, broadening the use of these approaches, and the learning capacity from implementation and verification.

\section{Stakeholder feedback on the national RAP process}

Mr. Ben Mache, Head of Crops Agricultural Technical and Extension Services, said that dialogues as the RAP development had initiated help to create conditions and mechanisms that can leverage uptake of technologies and cater to shock situations, in preparation for agriculture under future climate scenarios.

The importance of sharing information on technologies was also stressed. "Informing crop improvement program is critical, especially for supporting the highly vulnerable smallholder farmers in marginal areas to adapt to climate variability and change", said Dr. Dumisani Kutywayo, Director Crops Research Division, Department of Research and Specialists Services.

"It can guide policy processes and facilitate dialogue with research towards integrated farming systems", said Dr. Reneth Mano, Agricultural Economist, Livestock and Meat Advisory Council, Zimbabwe.

The impact of national level policies to shape the future of women in farming was among the issues discussed. "Women carry the major burden of farming in Zimbabwe, and there is no sign that this is going to change in the future; it might rather increase as male labour leaves rural areas for wage labour opportunities. 
Hence, what would it mean if policy evolved to ensure women equal control over resources, production factors, and information? What would be the implications for food security and nutrition?"

\section{Shared Socio-Economic Pathways for European Agriculture: The Eur-Agri-SSPs}

\section{Objectives}

The national RAPs processes have been motivated by the need for scenarios to support consistency in policy processes across multiple scales, verified through a series of regional case studies. A similar motivation led to the development of Eur-AgriSSPs. A consortium of 17 universities and research institutes across Europe has developed a set of five qualitative scenarios, i.e., storylines, for European agriculture until 2050, the Eur-Agri-SSPs. The storylines aim to enrich and refine the SSPs with a continental and sectoral component, and to inform integrated assessments of agriculture and food systems by overcoming gaps in scenario parameters. The continental scale has been chosen because the national agriculture and food sectors in Europe are strongly interwoven economically and politically, and national developments highly depend on decisions made at European scale. The time horizon of 2050 is of interest for sectoral developments and seems reasonable for stakeholder engagement.

\section{Methods}

The Eur-Agri-SSP development process followed a newly developed protocol in order to enhance conceptual and methodological transparency, and to increase replicability and comparability of integrated assessments (Mitter et al., 2019). The protocol is scale-neutral, such that it can be applied at national, regional, and local levels to further downscale the Eur-Agri-SSPs in a consistent and transparent way. As summarized in Box 2, the protocol defines nine working steps and suggests adequate methods and necessary feedback loops for each step.

The research was conducted in close co-operation with European stakeholders related to the agriculture and food sectors. Stakeholder engagement was particularly useful for identifying and prioritizing storyline elements (working step 3) as well as for checking the storylines for internal consistency (working step 5). In total, stakeholders from 60 organizations and institutions working at European or national scale have contributed to the storylines either during a workshop or in a semi-structured interview. They are characterized by diverse backgrounds and topical expertise working in administration, advocacy groups, policy making, private or public 
1. Defining key characteristics of the storylines

2. Establishing a team and setting up a stakeholder group

3. Defining storyline elements

4. Drafting storylines

5. Consistency checks

6. Developing presentation formats

7. Peer and stakeholder review and revision of storylines

8. Dissemination of storylines

9. Evaluating collaboration for storyline development

Box 2. Working steps to develop the Eur-Agri-SSPs as defined in the protocol (Mitter et al., 2019).

enterprises, private or public non-profit organizations, public inter-governmental organizations, and research.

\section{Results - The Eur-Agri-SSPs}

The Eur-Agri-SSPs outline plausible developments of socio-economic, environmental, and technological conditions by following the SSP matrix architecture (O'Neill et al., 2014, 2017). Hence, they describe plausible futures where challenges to mitigation, adaptation, or other sustainability issues increase or decrease. The protocolbased, iterative development shall ensure that the Eur-Agri-SSPs are consistent, both internally and with the SSPs, are clear and comprehensible, rich and comprehensive, and significantly different from each other. The level of detail is mainly driven by the needs of integrated assessment models at national to local level. While typical model inputs, such as changes in consumption, policies, or technology, and their relationships, are considered, the storylines should not anticipate typical model outputs, such as land use and land management choices.

Given the SSP architecture, the Eur-Agri-SSPs describe contrasting developments of European agriculture: Eur-Agri-SSP1 emphasizes sustainable development. It harmonizes consumption patterns with European production potentials under a green technological development paradigm. Eur-Agri-SSP2 follows historical patterns. It is the typical business-as-usual scenario that balances economic growth, high consumption patterns, and environmental protection. In Eur-AgriSSP3, distrust leads to renationalization. This impacts the agricultural production and consumption patterns with pressures on land resources from a hampered technological development. In Eur-Agri-SSP4, future development is dominated by a business-oriented, wealthy upper class. It segregates land use systems across Europe with strong agricultural industrialization patterns. Eur-Agri-SSP5 is characterized 
by faith in material-intensive lifestyles, which dominate attitudes towards environmental protection. Strong economic growth leads to resource-intensive technological development in agriculture.

For details on the storylines, we refer to Mitter et al. (2020) and the official website https://eur-agri-ssps.boku.ac.at/.

\section{Commonalities and differences between the RAPS and the Eur-Agri-SSP process}

The basic idea of developing RAPs and Eur-Agri-SSPs is similar. Both activities aim to improve the understanding of agriculture and food systems, and to inform regional quantitative integrated assessment models by following a structured and goal-oriented process. Interdisciplinary and participatory approaches have been applied in order to increase mutual understanding between researchers, policymakers, and representatives of the society, and to strengthen knowledge exchange and collaboration for meeting societal challenges. However, while the RAPs have been developed bottom-up and describe plausible states of the future, the Eur-Agri-SSPs follow a top-down, nested approach, and focus on plausible directions of change.

The bottom-up approach has the clear advantage that stakeholders' views can be integrated, which is crucial for RAPs at regional and national levels. This allows stakeholders to come up with their preferences and visions, i.e., a normative scenario component, during the scenario development. The top-down, nested approach of the Eur-Agri-SSPs ensures consistency with the global SSPs and proved effective at the European level. The available quantitative information on SSPs, e.g., data from marker scenarios (see the SSP data base https://tntcat.iiasa.ac.at/SspDb), can be integrated more easily. On the national or regional level, however, the SSP logic and its corresponding dominance of scenario hierarchies across scales may challenge stakeholder processes. Efforts may need to be taken to achieve stakeholder buy-in.

\section{Next steps for the Eur-Agri-SSPS}

Extensions of the Eur-Agri-SSPs shall comprise downscaling activities to national and sub-sectoral levels. For instance, regional or national storylines for the agricultural sector shall be developed in Austria, Estonia, Germany, and Switzerland within the SALBES project and regional storylines with a focus on soil management are being developed within BonaRes and SUSTAg.

\section{Discussion}

While the first generation of RAPs focused much on setting up the tools and engaging stakeholders to generate contrasting narratives, the advanced applications looked more at relevance for users. The process was designed to acknowledge uncertainty 
about future decisions, yet engaging stakeholders to come up with desirable trajectories, discuss investment and research priorities for future farming conditions, while being conscious about costs and impacts on society, implications for vulnerability, equity, gender, environment.

One of the major outcomes across sites and scenarios was the agreement that the need to produce more nutritious foods for the ever-growing populations will result in investments that would increase productivity in a future with climate change, implying that agricultural potential is currently underutilized. If investments were made under current conditions with adequate technologies, infrastructure, and policies, they were projected to help closing productivity gaps and facilitate adaptation to climate change in the future. The comparison of national and sub-national RAPs confirmed what appeared as a disconnect between the national policies and how they are implemented at state and local levels (in the current conditions). The RAPs can be used as a tool to verify/validate the consistency of policy implementation at different levels.

\section{Lessons from the RAP Process}

Unanimously, stakeholder views and preferences were for creating conditions that support sustainability pathways, which as the analysis proved, were also more economically viable and with faster returns on climate change adaptation, also supported functional structures and equity in society. The RAPs processes also highlighted the advantage of participatory planning approaches to develop a joint definition of desired future states and setting the basis for influencing decisions towards sustainability outcomes. The process brought forward important contributions to the SDG planning and investment priorities.

- Define systems boundaries: With complexity of farming systems and dynamic changes in context, one challenge is to delineate predominant farming systems, for which climate change impacts and adaptation would be relevant. Clear definition of farming systems coverage with similar patterns is part of the initial RAPs process and helps to guide the change in key drivers and estimation of model parameters. Similarly, it is important to review the underlying assumptions for each narrative as socio-political conditions and governance can involve abrupt changes.

- Ensure data quality: Robust projections depend on quality data. Primary data are costly and often point-based; for meaningful extrapolation they need to be complemented and verified with secondary data, involving national census and other national and global data sets. Yet, data collection tools in use often do not collect the information required for climate change impact projections, e.g., prices and costs, productivity under smallholder conditions. Gaps also exist between local and global estimations. There is, hence, a need to upgrade data collection tools and verify the rationale beyond global projections using local assessments. 
- Integrate climate change modeling with ongoing projects: Embedding the scenario development with other projects, with modeling as one element in a journey of ongoing collaborations where existing knowledge about the current farming systems can be beneficial to the RAPs development and the RIAs and at the same time can facilitate the estimation of multiple and interrelated changes under future conditions and climate change.

- Engage stakeholders to assess and verify data: Engaging stakeholders from the beginning about why and how we assess climate change impacts is a way to bring robust research procedures into country decision processes, and vice versa, advise research on priority areas, provide inputs for technical options, and build on what has been done. Making representatives of national organizations part of the research team helps to further align the research with country programs, verify research and capacity development needs, supporting national climate action as a strategy to bring research results to scale.

- Co-design pathways: Bringing in a diversity of experts at the various levels for a joint dialogue with scientists helps to capture the inherent knowledge of farming systems, their internal and external linkages, and the identification of institutional barriers. It can help to verify the plausibility of scientific knowledge and global simulations to create future worlds that represent real possible change.

- Evaluate impacts with policy and decision makers: Proposed policy and technology interventions can help to set priorities on what needs to change and how to endorse the change.

- Improving protocols for scenario design and use: A series of case studies is a way to generate knowledge through exposure, validation, and improvement. Utilizing the growing body of literature and experience can permanently improve availability of data and processes at local to regional levels, and influence a change in processes.

\section{Conclusions}

The RAPs processes were useful to unpack the complexity of technical, institutional, and policy issues from local to national levels. They promoted scientists' confidence for distilling powerful key messages that can be used to inform decision processes. Nurturing opportunities for stakeholders' contributions supported buy-in, ownership, and continuity, e.g., in jointly designed research processes, options verified with communities, and from local to national levels. Each research team member was proficient in the research objectives and contents, across disciplines, to be able to guide multi-disciplinary dialogue with stakeholders. Inconsistencies, opportunities, and challenges were identified, beyond individual disciplines and affiliations, and across local (district) provincial and national levels. A vertical and horizontal integration was fundamental to achieve agreement on the RAPs narratives across 
scales and disciplines. Establishing solid research results and understanding local level conditions (opportunities and challenges) and taking that to national levels was seen as the right direction, as this provides facts and legitimacy, where decisions are often political rather than science-based.

Engaging national research organizations and ministries in scenario generation and multi-model simulations would be transformative. Accessing and using scenarios for strategic planning can support and enhance vulnerability assessments, adaptation costing, development of National Adaptation Plans (NAPs) and Nationally Determined Contributions (NDCs), and improve the development and feasibility of projects (e.g., Green Climate Fund projects), academic studies and national communications.

\section{Annex 1. RAP Trend Tables}

See Tables A.1-A.17 for RAP trend tables from the AgMIP Regional Integrated Assessments.

\section{Pakistan}

Table A.1 shows the direction of change in variables for Sustainable (Green RAP) and Unsustainable (Grey RAP) Development Pathways. Unsustainable development would result in higher population growth, sheer land fragmentation, and low growth in other sectors, high unemployment, unstable markets, and high inflation in the economy. Sustainable development policies will lead to moderate increase in household size, small increase in non-farm income, small increase in herd size, stable markets, and low inflation in input and output markets.

Table A.1. Pakistan, Punjab: Trends for Green and Grey RAPs.

\begin{tabular}{|l|l|l|}
\hline Variable & $\begin{array}{l}\text { Sustainable development Pathway } \\
\text { (Green RAP) }\end{array}$ & $\begin{array}{l}\text { Unsustainable development } \\
\text { Pathway (Grey RAP) }\end{array}$ \\
\hline Farm Size & Moderate Decrease & Large Decrease \\
\hline Household Size & Moderate Increase & Large Increase \\
\hline Non-Agricultural Income & Small Increase & Small Increase \\
\hline Herd Size & Small Increase & Large Decrease \\
\hline Input Prices & Moderate Increase & Large Increase \\
\hline Out Prices & Moderate Increase & Large Increase \\
\hline
\end{tabular}


Table A.2. Pakistan, Punjab: Drivers and storylines for the Green RAP.

\begin{tabular}{|c|c|c|}
\hline Indicators & $\begin{array}{l}\text { Direction } \\
\text { of Change }\end{array}$ & Narrative for Green RAP \\
\hline Farm Size & Decrease & $\begin{array}{l}\text { The law of inheritance is the major determinant of division of } \\
\text { farms in Pakistan. Mechanization, high returns and } \\
\text { emergence of farm business as an enterprise will decrease at } \\
\text { a lower scale }\end{array}$ \\
\hline Household Size & Increase & $\begin{array}{l}\text { Population is increasing due to religious and social reasons, } \\
\text { multiple marriages }\end{array}$ \\
\hline $\begin{array}{l}\text { Non- } \\
\text { Agricultural } \\
\text { Income }\end{array}$ & Increase & $\begin{array}{l}\text { Profitability in agriculture sector, High Unemployment rate, } \\
\text { Increase in literacy rate in urban area, awareness, emergence } \\
\text { of new enterprises }\end{array}$ \\
\hline Herd Size & Increase & $\begin{array}{l}\text { Profitability, high demand of livestock products due to increase } \\
\text { in incomes, economic potential for establishment of milk } \\
\text { industry. }\end{array}$ \\
\hline Input Prices & Increase & $\begin{array}{l}\text { Variable cost of production will increase with the same factor } \\
\text { as output price increases. }\end{array}$ \\
\hline Out Prices & Increase & $\begin{array}{l}\text { For output prices without climate change we have used the } \\
\text { global projections and according to our regional conditions } \\
\text { rationalize the output prices with climate change. }\end{array}$ \\
\hline
\end{tabular}

Table A.3. Pakistan, Punjab: Drivers and storylines for the Grey RAP.

\begin{tabular}{|c|c|c|}
\hline Indicators & $\begin{array}{l}\text { Direction } \\
\text { of Change }\end{array}$ & Narrative for Grey RAP \\
\hline Farm Size & Decrease & $\begin{array}{l}\text { Land fragmentation is unavoidable in the presence of Law of } \\
\text { Inheritance, without land policy it will decrease at large scale }\end{array}$ \\
\hline Household Size & Increase & $\begin{array}{l}\text { Population pressure, Religious and social norms, multiple } \\
\text { marriages, desire for baby boy in rural society }\end{array}$ \\
\hline $\begin{array}{l}\text { Non- } \\
\text { Agricultural } \\
\text { Income }\end{array}$ & Increase & $\begin{array}{l}\text { Industrialization, Urbanization, High returns on investment in } \\
\text { other sectors, literacy rate increase will increase the } \\
\text { non-farm income but at the same time population pressure } \\
\text { and unemployment rate will also push the non-farm income } \\
\text { at the present level }\end{array}$ \\
\hline Herd Size & Decrease & $\begin{array}{l}\text { Agricultural land will be declined and there will be intense } \\
\text { competition between cash crops and fodder. Livestock will } \\
\text { emerge as an enterprise and large farms on commercial basis } \\
\text { will establish, it will be non-profitable at lower scale due to } \\
\text { easy access of farm machinery, new breeds, and progressive } \\
\text { farm management. }\end{array}$ \\
\hline $\begin{array}{l}\text { Variable Cost of } \\
\text { Production }\end{array}$ & Increase & $\begin{array}{l}\text { Variable cost of production will increase with the same factor } \\
\text { as output price increases. }\end{array}$ \\
\hline Output Prices & Increase & $\begin{array}{l}\text { For output prices without climate change we have used the } \\
\text { global projections and according to our regional conditions } \\
\text { rationalize the output prices with climate change. }\end{array}$ \\
\hline
\end{tabular}




\section{South Africa}

Table A.4. South Africa, The Free State: Drivers and trends for the Green RAP.

\begin{tabular}{|c|c|c|c|c|c|c|c|c|c|c|c|}
\hline Category & Indicator & $\begin{array}{l}\text { Variable/ } \\
\text { of Change }\end{array}$ & $\begin{array}{l}\text { Direction } \\
\text { of Change }\end{array}$ & $\begin{array}{l}\text { Magnitude } \\
\text { Change }\end{array}$ & $\begin{array}{l}\text { Rationale for } \\
\text { Direction and } \\
\text { Magnitude of } \\
\quad \text { Period }\end{array}$ & $\begin{array}{l}\text { Percentage } \\
\text { Change } \\
\text { Over the } \\
\text { Period }\end{array}$ & $\begin{array}{l}\text { Rationale for } \\
\text { Percentage } \\
\text { Change Over } \\
\text { Agreement }\end{array}$ & Confidence & $\begin{array}{c}\text { Scale of } \\
\text { Influence } \\
\text { (National, } \\
\text { State, } \\
\text { Local) }\end{array}$ & $\begin{array}{l}\text { Type of RAP } \\
\text { Variable } \\
\text { (Direct or } \\
\text { Indirect } \\
\text { Effect on } \\
\text { Model } \\
\text { Parameters) }\end{array}$ & $\begin{array}{l}\text { Element in The } \\
\text { Model to Change }\end{array}$ \\
\hline \multirow[t]{2}{*}{ Biophysical } & $\begin{array}{l}\text { Soil fertility } \\
\text { Soil pro- } \\
\text { ductivity }\end{array}$ & Increase & Small to Medium & $\begin{array}{l}\text { Must increase to feed the } \\
\text { nation. We must } \\
\text { change the way we } \\
\text { do things }\end{array}$ & $3 \%$ & Conservation farming & Medium & Medium & National & Direct & $\begin{array}{c}\text { Variable cost, fixed } \\
\text { cost and cost to } \\
\text { change system }\end{array}$ \\
\hline & $\begin{array}{l}\text { Water use } \\
\text { efficiency }\end{array}$ & Increase & Small to Medium & $\begin{array}{l}\text { Technologies will be } \\
\text { available, e.g., drip } \\
\text { irrigation. Farmers } \\
\text { will change systems } \\
\text { that are most suited } \\
\text { to crop of interest. } \\
\text { Irrigation systems } \\
\text { will minimize water } \\
\text { loss. This can be } \\
\text { taught to people. } \\
\text { Water harvesting } \\
\text { systems. } \\
\text { Households will be } \\
\text { water conscious. }\end{array}$ & $10 \%$ & $\begin{array}{l}\text { Conservation farming } \\
\text { and improved } \\
\text { technology }\end{array}$ & Medium & High & National & Direct & $\begin{array}{c}\text { Variable cost, fixed } \\
\text { cost and cost to } \\
\text { change system }\end{array}$ \\
\hline \multirow[t]{4}{*}{ Institutional/Policy } & $\begin{array}{l}\text { Agricultural } \\
\text { input sub- } \\
\text { sidization }\end{array}$ & No change & No change & Market-driven economy & $5 \%$ & $\begin{array}{l}\text { Food security, stability } \\
\text { in food price } \\
\text { structure }\end{array}$ & Low & Low & National & Direct & Fixed cost \\
\hline & $\begin{array}{l}\text { Sustainable } \\
\quad \text { develop- } \\
\text { ment } \\
\text { focus }\end{array}$ & Increase & Large & $\begin{array}{l}\text { Increased awareness - } \\
\text { tax breaks, subsidy, } \\
\text { insurance }\end{array}$ & $5 \%$ & $\begin{array}{l}\text { Increase in current } \\
\text { support packages }\end{array}$ & Medium & Medium & National & Direct & Fixed cost \\
\hline & $\begin{array}{l}\text { Access to } \\
\text { market }\end{array}$ & Increase & Medium to Large & $\begin{array}{l}\text { No barriers with an } \\
\text { increased demand, } \\
\text { open to new } \\
\text { markets, global } \\
\text { opportunities - } \\
\text { tariffs }\end{array}$ & $15 \%$ & $\begin{array}{c}\text { Free and fair trade, } \\
\text { international } \\
\text { agreements }\end{array}$ & Medium & Medium & National & Direct & Price \\
\hline & $\begin{array}{l}\text { Minimum } \\
\text { wages on } \\
\text { farm }\end{array}$ & Increase & Large & $\begin{array}{l}\text { More market } \\
\text { opportunities, more } \\
\text { efficient/profitable } \\
\text { production }\end{array}$ & $6 \%$ & Current legislation & High & Low & National & Direct & Fixed cost \\
\hline
\end{tabular}


Table A.4. (Continued)

\begin{tabular}{|c|c|c|c|c|c|c|c|c|c|c|c|}
\hline Category & Indicator & $\begin{array}{l}\text { Variable/ } \\
\text { of Change }\end{array}$ & $\begin{array}{l}\text { Direction } \\
\text { of Change }\end{array}$ & $\begin{array}{l}\text { Magnitude } \\
\text { Change }\end{array}$ & $\begin{array}{l}\text { Rationale for } \\
\text { Direction and } \\
\text { Magnitude of } \\
\quad \text { Period }\end{array}$ & $\begin{array}{l}\text { Percentage } \\
\text { Change } \\
\text { Over the } \\
\text { Period }\end{array}$ & $\begin{array}{l}\text { Rationale for } \\
\text { Percentage } \\
\text { Change Over } \\
\text { Agreement }\end{array}$ & Confidence & $\begin{array}{l}\text { Scale of } \\
\text { Influence } \\
\text { (National, } \\
\text { State, } \\
\text { Local) }\end{array}$ & $\begin{array}{c}\text { Type of RAP } \\
\text { Variable } \\
\text { (Direct or } \\
\text { Indirect } \\
\text { Effect on } \\
\text { Model } \\
\text { Parameters) }\end{array}$ & $\begin{array}{l}\text { Element in The } \\
\text { Model to Change }\end{array}$ \\
\hline \multirow[t]{2}{*}{ Socio-Economic } & Farmland size & Increase & $\begin{array}{l}\text { Small to } \\
\text { Medium }\end{array}$ & Economy of scale & $10 \%$ & $\begin{array}{l}\text { Current trend of } \\
\text { economies of scale } \\
\text { will continue }\end{array}$ & Medium & Medium & National & Direct & Fixed cost \\
\hline & $\begin{array}{l}\text { Off-farm } \\
\text { incomes }\end{array}$ & Increase & $\begin{array}{l}\text { Medium to } \\
\text { Large }\end{array}$ & $\begin{array}{c}\text { Diversification and more } \\
\text { opportunities due to } \\
\text { lower profit margins }\end{array}$ & $3 \%$ & $\begin{array}{l}\text { Increase interest in green } \\
\text { lifestyle }\end{array}$ & Medium & Medium & National & Direct & Off-farm income \\
\hline \multirow[t]{2}{*}{ Technology } & $\begin{array}{l}\text { Use of Energy } \\
\text { (green) }\end{array}$ & Increase & $\begin{array}{l}\text { Medium to } \\
\text { Large }\end{array}$ & $\begin{array}{l}\text { Will be using energy } \\
\text { more efficiently. } \\
\text { Increase in solar and } \\
\text { wind energy. } \\
\text { Investment into } \\
\text { biofuels. Investment } \\
\text { into energy derived } \\
\text { from bacteria and } \\
\text { algae. }\end{array}$ & $10 \%$ & $\begin{array}{l}\text { Increased use of solar } \\
\text { energy and biodiesel }\end{array}$ & High & Medium & National & Direct & $\begin{array}{l}\text { Variable cost, fixed } \\
\text { cost and cost to } \\
\text { change system }\end{array}$ \\
\hline & $\begin{array}{l}\text { Access to } \\
\text { informa- } \\
\text { tion and } \\
\text { latest tech- } \\
\text { nologies }\end{array}$ & Increase & Large & $\begin{array}{l}\text { Knowledge economy, } \\
\text { innovation, } \\
\text { improved } \\
\text { technology, } \\
\text { communication }\end{array}$ & $20 \%$ & $\begin{array}{l}\text { Access to smart } \\
\text { phone/technology/ } \\
\text { drones/satellite } \\
\text { imagery }\end{array}$ & High & Medium & National & Direct & $\begin{array}{l}\text { Variable cost, fixed } \\
\text { cost and cost to } \\
\text { change system }\end{array}$ \\
\hline $\begin{array}{l}\text { Price from } \\
\text { national/global } \\
\text { models }\end{array}$ & Input prices & Increase & Medium & $\begin{array}{l}\text { Due to the importation } \\
\text { of inputs } \\
\text { (chemicals), } \\
\text { increase in } \\
\text { constrained } \\
\text { resources }\end{array}$ & $10 \%$ & $\begin{array}{l}\text { Quick access to } \\
\text { international } \\
\text { developed } \\
\text { technologies at } \\
\text { competitive price }\end{array}$ & High & Medium & National & Direct & $\begin{array}{l}\text { Fixed and variable } \\
\text { cost }\end{array}$ \\
\hline
\end{tabular}


Table A.5. South Africa, The Free State: Drivers and trends for the Grey RAP.

\begin{tabular}{|c|c|c|c|c|c|c|c|c|c|c|c|}
\hline Category & Indicator & $\begin{array}{c}\text { Variable/ } \\
\text { of Change }\end{array}$ & $\begin{array}{l}\text { Direction } \\
\text { of Change }\end{array}$ & $\begin{array}{l}\text { Magnitude } \\
\text { Change }\end{array}$ & $\begin{array}{c}\text { Rationale for } \\
\text { Direction and } \\
\text { Magnitude of } \\
\text { Period }\end{array}$ & $\begin{array}{l}\text { Percentage } \\
\text { Change } \\
\text { Over the } \\
\text { Period }\end{array}$ & $\begin{array}{c}\text { Rationale for } \\
\text { Percentage } \\
\text { Change Over } \\
\text { Agreement }\end{array}$ & Confidence & $\begin{array}{c}\text { Scale of } \\
\text { Influence } \\
\text { (National, } \\
\text { State, } \\
\text { Local) }\end{array}$ & $\begin{array}{l}\text { Type of RAP } \\
\text { Variable } \\
\text { (Direct or } \\
\text { Indirect } \\
\text { Effect on } \\
\text { Model } \\
\text { Parameters) }\end{array}$ & $\begin{array}{l}\text { Element in The } \\
\text { Model to Change }\end{array}$ \\
\hline \multirow[t]{3}{*}{ Biophysical } & Soil fertility & Decrease & Large & $\begin{array}{l}\text { Increased erosion, } \\
\text { tragedy of the } \\
\text { commons } \\
\text { (Everyone can } \\
\text { use, but all will } \\
\text { share in the } \\
\text { abuse) }\end{array}$ & $-1 \%$ & $\begin{array}{l}\text { Production methods } \\
\text { that ensure } \\
\text { highest yield } \\
\text { irrespective of } \\
\text { method }\end{array}$ & Medium & Low & National & Direct & $\begin{array}{c}\text { Variable cost, fixed } \\
\text { cost and cost to } \\
\text { change system }\end{array}$ \\
\hline & $\begin{array}{l}\text { Water availability/ } \\
\text { quality }\end{array}$ & Decrease & Small & $\begin{array}{l}\text { Depends on what } \\
\text { will happen }\end{array}$ & $-5 \%$ & $\begin{array}{l}\text { Use of chemicals } \\
\text { Water pollution } \\
\text { Reduction of } \\
\text { water } \\
\text { allocation/use } \\
\text { for mines }\end{array}$ & Medium & Medium & National & Direct & $\begin{array}{l}\text { Change in irrigated } \\
\text { area }\end{array}$ \\
\hline & $\begin{array}{l}\text { Pests, weeds and } \\
\text { diseases }\end{array}$ & Increase & No change & $\begin{array}{l}\text { Some pest, weeds } \\
\text { and diseases } \\
\text { will increase } \\
\text { whilst others } \\
\text { will decrease }\end{array}$ & $0 \%$ & $\begin{array}{l}\text { Increased use of } \\
\text { chemicals }\end{array}$ & Low & Low & National & Direct & $\begin{array}{l}\text { Variable cost, fixed } \\
\text { cost (higher } \\
\text { vehicle } \\
\text { maintenance) }\end{array}$ \\
\hline \multirow[t]{3}{*}{ Institutional/Policy } & Access to market & Decrease & & $\begin{array}{l}\text { Market system } \\
\text { collapse, poor } \\
\text { infrastructure }\end{array}$ & $-5 \%$ & Domestic focus & Medium & Low & National & Direct & $\begin{array}{l}\text { Fixed cost (higher } \\
\text { taxes) }\end{array}$ \\
\hline & $\begin{array}{l}\text { Municipal } \\
\text { infrastructure } \\
\text { maintenance } \\
\text { and } \\
\text { development }\end{array}$ & Decrease & Large & $\begin{array}{l}\text { No resource to } \\
\text { finance } \\
\text { infrastructure, } \\
\text { not enough } \\
\text { production }\end{array}$ & $-7 \%$ & $\begin{array}{l}\text { Diminished } \\
\text { capacity/less } \\
\text { investment }\end{array}$ & High & Medium & National & Direct & $\begin{array}{l}\text { Fixed cost (higher } \\
\text { taxes) }\end{array}$ \\
\hline & $\begin{array}{l}\text { Minimum wages on } \\
\text { farm / } \\
\text { administrative } \\
\text { costs }\end{array}$ & Increase & Large & $\begin{array}{l}\text { Low production, } \\
\text { low } \\
\text { profitability }\end{array}$ & $10 \%$ & $\begin{array}{l}\text { Inflation driven - } \\
\text { collective } \\
\text { bargaining in } \\
\text { agricultural } \\
\text { sector }\end{array}$ & Medium & Medium & National & Direct & $\begin{array}{l}\text { Fixed cost (higher } \\
\text { wages) }\end{array}$ \\
\hline
\end{tabular}


Table A.5. (Continued)

\begin{tabular}{|c|c|c|c|c|c|c|c|c|c|c|c|}
\hline Category & Indicator & $\begin{array}{l}\text { Variable/ } \\
\text { of Change }\end{array}$ & $\begin{array}{l}\text { Direction } \\
\text { of Change }\end{array}$ & $\begin{array}{l}\text { Magnitude } \\
\text { Change }\end{array}$ & $\begin{array}{l}\text { Rationale for } \\
\text { Direction and } \\
\text { Magnitude of } \\
\quad \text { Period }\end{array}$ & $\begin{array}{l}\text { Percentage } \\
\text { Change } \\
\text { Over the } \\
\text { Period }\end{array}$ & $\begin{array}{c}\text { Rationale for } \\
\text { Percentage } \\
\text { Change Over } \\
\text { Agreement }\end{array}$ & Confidence & $\begin{array}{c}\text { Scale of } \\
\text { Influence } \\
\text { (National, } \\
\text { State, } \\
\text { Local) }\end{array}$ & $\begin{array}{c}\text { Type of RAP } \\
\text { Variable } \\
\text { (Direct or } \\
\text { Indirect } \\
\text { Effect on } \\
\text { Model } \\
\text { Parameters) }\end{array}$ & $\begin{array}{l}\text { Element in The } \\
\text { Model to Change }\end{array}$ \\
\hline & $\begin{array}{l}\text { Policy uncertainty } \\
\text { challenging } \\
\text { investment } \\
\text { implementation }\end{array}$ & Increase & Large & $\begin{array}{l}\text { Policy environment } \\
\text { not conducive, } \\
\text { government not } \\
\text { responsive, } \\
\text { lack of } \\
\quad \text { information }\end{array}$ & $10 \%$ & $\begin{array}{l}\text { Corruption/no } \\
\text { cooperation } \\
\text { between } \\
\text { government } \\
\text { departments }\end{array}$ & High & Medium & National & Indirect & \\
\hline \multirow[t]{2}{*}{ Socio-Economic } & Farmland size & Increase & Medium to Large & Economy of scale & $15 \%$ & $\begin{array}{l}\text { Horizontal } \\
\quad \text { expansion due } \\
\text { to diminished } \\
\text { ecosystem } \\
\text { services }\end{array}$ & Medium & Medium & National & Direct & Area \\
\hline & Off-farm incomes & Decrease & Medium & $\begin{array}{l}\text { Intensified } \\
\quad \text { agricultural } \\
\text { production } \\
\text { (specialization) }\end{array}$ & $-3 \%$ & $\begin{array}{l}\text { No time for } \\
\text { off-farm } \\
\text { income and } \\
\text { little incentive } \\
\text { for agri-tourism }\end{array}$ & Medium & Medium & National & Direct & Off-farm income \\
\hline Technology & $\begin{array}{l}\text { Use of energy } \\
\text { (green) }\end{array}$ & No change & No change & $\begin{array}{l}\text { Hydraulic } \\
\text { fracturing in } \\
\text { the Karoo }\end{array}$ & $-1 \%$ & $\begin{array}{l}\text { Fossil fuel usage } \\
\text { increase/over } \\
\text { extension of } \\
\text { government } \\
\text { services due to } \\
\text { investment in } \\
\text { nuclear power }\end{array}$ & Medium & Low & National & Direct & $\begin{array}{l}\text { Variable cost, fuel } \\
\text { price }\end{array}$ \\
\hline
\end{tabular}




\section{Kenya}

Table A.6. Kenya: Drivers and trends for Green and Grey RAPs.

\begin{tabular}{|c|c|c|c|c|}
\hline & \multicolumn{2}{|r|}{ Green RAP } & \multicolumn{2}{|r|}{ Grey RAP } \\
\hline & Trend & Description & Trend & Description \\
\hline Household Size & 0.8 & $\begin{array}{l}\text { From discussions at } \\
\text { RAPs meeting. }\end{array}$ & 1.2 & $\begin{array}{l}\text { From discussions at } \\
\text { RAPs meeting. }\end{array}$ \\
\hline $\begin{array}{l}\text { Off-farm } \\
\text { Income }\end{array}$ & 1.5 & $\begin{array}{l}\text { From discussions at } \\
\text { RAPs meeting. }\end{array}$ & 1.8 & $\begin{array}{l}\text { From discussions at } \\
\text { RAPs meeting. }\end{array}$ \\
\hline \multicolumn{5}{|l|}{ Crop Production } \\
\hline Farm Size & 1.4 & $\begin{array}{l}\text { From discussions at } \\
\text { RAPs meeting. CV } \\
\text { increases by } 10 \% \\
\text { also. }\end{array}$ & 1 & $\begin{array}{l}\text { From discussions at } \\
\text { RAPs meeting. CV } \\
\text { increases by } 20 \% \\
\text { also. }\end{array}$ \\
\hline Maize Area & $1.4,0.84$ & $\begin{array}{l}\text { Increases in proportion } \\
\text { to farm size. } \\
\text { Low-milk strata } \\
\text { allocates } 40 \% \text { of } \\
\text { future area to napier } \\
\text { grass leading to a } \\
0.84 \text { trend for maize } \\
\text { area. }\end{array}$ & $0.8-1.1$ & $\begin{array}{l}\text { Low-milk strata } \\
\text { allocates } 20 \% \text { of } \\
\text { area to napier grass } \\
\text { leading to a } 0.80 \\
\text { trend for maize area. } \\
\text { Other low potential } \\
\text { farms do not change } \\
\text { allocation } \\
\text { (trend }=1 \text { ). The } \\
\text { high and medium } \\
\text { potential zones } \\
\text { increase maize area } \\
\text { by } 10 \% \text {. }\end{array}$ \\
\hline Maize Yield & 1.7 & IFPRI IMPACT trend. & 1.44 & IFPRI IMPACT trend. \\
\hline $\begin{array}{l}\text { Maize Price (no } \\
\text { CC) }\end{array}$ & 1.51 & IFPRI IMPACT trend. & 1.37 & IFPRI IMPACT trend. \\
\hline $\begin{array}{l}\text { Maize Price } \\
\text { (with CC) }\end{array}$ & 1.6 & IFPRI IMPACT trend. & 1.57 & IFPRI IMPACT trend. \\
\hline Maize Cost & 1.51 & $\begin{array}{l}\text { Assumed same as } \\
\text { maize price. } \\
\text { Increases in proportion } \\
\text { to farm size. } \\
\text { Low-milk }\end{array}$ & 1.37 & $\begin{array}{c}\text { Assumed same as } \\
\text { maize price. }\end{array}$ \\
\hline $\begin{array}{l}\text { Other Crops } \\
\text { Area }\end{array}$ & $1.4,0.84$ & $\begin{array}{l}\text { strata allocates } 40 \% \text { of } \\
\text { future area to napier } \\
\text { grass leading to a } \\
0.84 \text { trend for maize } \\
\text { area. }\end{array}$ & $0.8-1$ & $\begin{array}{l}\text { Changes in accordance } \\
\text { to the maize area } \\
\text { change for each } \\
\text { strata. }\end{array}$ \\
\hline $\begin{array}{l}\text { Other Crops } \\
\text { Yield }\end{array}$ & 2.16 & $\begin{array}{l}\text { IFPRI IMPACT } \\
\text { aggregate trend.* }\end{array}$ & 1.95 & $\begin{array}{l}\text { IFPRI IMPACT } \\
\text { aggregate trend.* }\end{array}$ \\
\hline
\end{tabular}


Table A.6. (Continued)

\begin{tabular}{|c|c|c|c|c|}
\hline & \multicolumn{2}{|r|}{ Green RAP } & \multicolumn{2}{|r|}{ Grey RAP } \\
\hline & Trend & Description & Trend & Description \\
\hline $\begin{array}{l}\text { Other Crops } \\
\text { Price (no CC) }\end{array}$ & 1.18 & $\begin{array}{l}\text { IFPRI IMPACT } \\
\text { aggregate trend.* }\end{array}$ & 1.35 & $\begin{array}{l}\text { IFPRI IMPACT } \\
\text { aggregate trend.* }\end{array}$ \\
\hline $\begin{array}{l}\text { Other Crops } \\
\text { Price (with } \\
\text { CC) }\end{array}$ & 1.41 & $\begin{array}{l}\text { IFPRI IMPACT } \\
\text { aggregate trend.* }\end{array}$ & 1.73 & $\begin{array}{l}\text { IFPRI IMPACT } \\
\quad \text { aggregate trend.* }\end{array}$ \\
\hline $\begin{array}{l}\text { Other Crops } \\
\text { Cost } \\
\text { Milk Production }\end{array}$ & 1.18 & $\begin{array}{l}\text { Assumed same as } \\
\text { other crops price. }\end{array}$ & 1.35 & $\begin{array}{l}\text { Assumed same as } \\
\text { other crops price. }\end{array}$ \\
\hline Herd Size & 1.35 & $\begin{array}{l}\text { From discussions at } \\
\text { RAPs meeting. CV } \\
\text { increases by } 25 \% \\
\text { also. }\end{array}$ & 1 & $\begin{array}{l}\text { From discussions at } \\
\text { RAPs meeting. CV } \\
\text { increases by } 35 \% \\
\text { also. }\end{array}$ \\
\hline Milk Yield & $1.36,1.5$ & $\begin{array}{l}\text { Approximate relative } \\
\text { yields from } \\
\text { improved feeding in } \\
\text { Shikuku et al. } \\
\text { (2017). The lower } \\
\text { value corresponds to } \\
\text { the high and } \\
\text { medium zones; the } \\
\text { higher value } \\
\text { corresponds to the } \\
\text { low zones. }\end{array}$ & $1.36,1.5$ & $\begin{array}{l}\text { Approximate relative } \\
\text { yields from } \\
\text { improved feeding in } \\
\text { Shikuku } \text { et al. } \\
\text { (2017). The lower } \\
\text { value corresponds to } \\
\text { the high and } \\
\text { medium zones; the } \\
\text { higher value } \\
\text { corresponds to the } \\
\text { low zones. }\end{array}$ \\
\hline $\begin{array}{l}\text { Milk Price (no } \\
\text { CC) }\end{array}$ & 1.21 & IFPRI IMPACT trend. & 1.12 & IFPRI IMPACT trend. \\
\hline $\begin{array}{l}\text { Milk Price (with } \\
\text { CC) }\end{array}$ & 1.23 & IFPRI IMPACT trend. & 1.14 & IFPRI IMPACT trend. \\
\hline Milk Cost & $1.65,1.82$ & $\begin{array}{l}\text { Changes with milk } \\
\text { yield and milk price. }\end{array}$ & $1.52,1.68$ & $\begin{array}{l}\text { Changes with milk } \\
\text { yield and milk price. }\end{array}$ \\
\hline
\end{tabular}

Table 5.4.2: Quantification of parameter changes under each RAP.

Note: $\mathrm{CV}=$ coefficient of variation.

* see Table 5.4.3 for aggregate trend calculations. 


\section{South India: Andhra Pradesh}

Table A.7. India, Andhra Pradesh (South India): Trend table for Green RAP ("Swarna" Andhra Pradesh).

\section{RAP 4: Inclusive pathway towards 'Swarna' Andhra Pradesh}
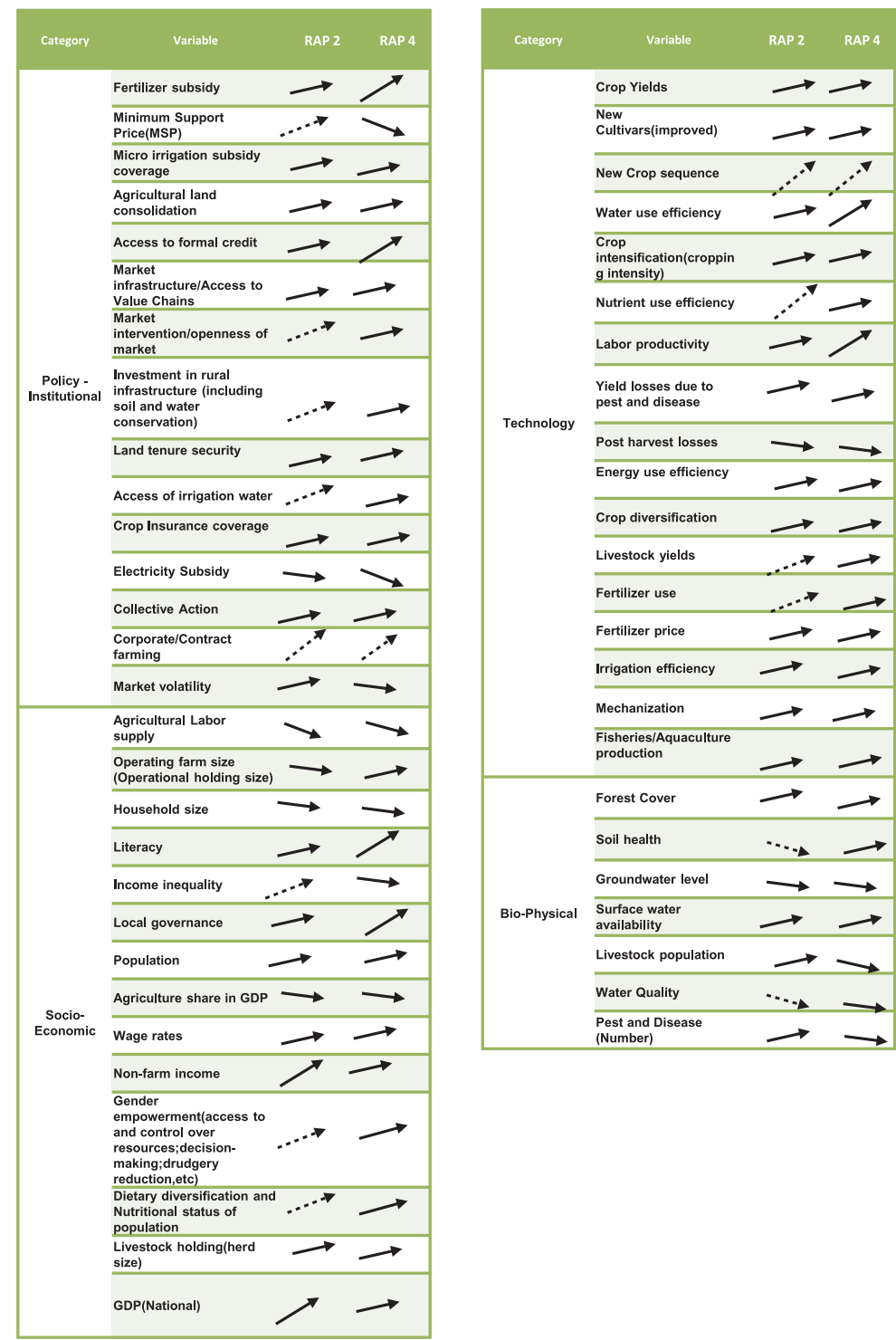

\begin{tabular}{|c|c|c|c|c|c|c|c|c|c|c|c|c|}
\hline & $\begin{array}{l}\text { No } \\
\text { change }\end{array}$ & $\begin{array}{l}\text { Small } \\
\text { increase }\end{array}$ & 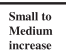 & $\begin{array}{l}\text { Mediuu } \\
\text { Increase }\end{array}$ & $\begin{array}{l}\text { Medium } \\
\text { to large } \\
\text { increase }\end{array}$ & $\begin{array}{l}\text { Large } \\
\text { increase }\end{array}$ & $\begin{array}{l}\text { Small } \\
\text { decrease }\end{array}$ & $\begin{array}{l}\text { Small to } \\
\text { medium } \\
\text { decrease }\end{array}$ & $\begin{array}{l}\text { Mediuus } \\
\text { decrease }\end{array}$ & $\begin{array}{l}\text { Medium } \\
\text { to Large } \\
\text { decrease }\end{array}$ & $\begin{array}{l}\text { Large } \\
\text { increase }\end{array}$ & Disappear \\
\hline $\begin{array}{l}\text { Direction } \\
\text { and } \\
\text { magnitude }\end{array}$ & $\longrightarrow$ & $\rightarrow$ & & & & & $\longrightarrow$ & & & & & $X$ \\
\hline
\end{tabular}


Table A.8. India, Andhra Pradesh (South India): Trend table for Grey RAP ("Dead End" Andhra Pradesh (AP wheel around Perils)).

\section{RAP 5: Unsustainable pathway towards 'Dead End' Andhra Pradesh (AP wheel around Perils)}

\begin{tabular}{|c|c|c|c|}
\hline Category & Variable & RAP 2 & RAP 5 \\
\hline \multirow{15}{*}{$\begin{array}{c}\text { Policy - } \\
\text { Institutional }\end{array}$} & Fertilizer subsidy & & \\
\hline & Minimum Support Price(MSP) & & \\
\hline & $\begin{array}{l}\text { Micro irrigation subsidy } \\
\text { coverage }\end{array}$ & & \\
\hline & Agricultural land consolidation & & \\
\hline & Access to formal credit & & \\
\hline & $\begin{array}{l}\text { Market infrastructure/Access } \\
\text { to Value Chains }\end{array}$ & & \\
\hline & $\begin{array}{l}\text { Market intervention/openness } \\
\text { of market }\end{array}$ & & \\
\hline & $\begin{array}{l}\text { Investment in rural } \\
\text { infrastructure (including soil } \\
\text { and water conservation) }\end{array}$ & & \\
\hline & Land tenure security & & \\
\hline & Access of irrigation water &..$\nabla$ & \\
\hline & Crop Insurance coverage & & \\
\hline & Electricity Subsidy & & \\
\hline & Collective Action & & \\
\hline & Corporate/Contract farming & & \\
\hline & Market volatility & & \\
\hline \multirow{14}{*}{ Socio-Economic } & Agricultural Labor supply & & \\
\hline & $\begin{array}{l}\text { Operating farm size } \\
\text { (Operational holding size) }\end{array}$ & & \\
\hline & Household size & & \\
\hline & Literacy & & \\
\hline & Income inequality & & \\
\hline & Local governance & & \\
\hline & Population & & \\
\hline & Agriculture share in GDP & & \\
\hline & Wage rates & & \\
\hline & Non-farm income & & \\
\hline & $\begin{array}{l}\text { Gender empowerment(access } \\
\text { to and control over } \\
\text { resources;decision- } \\
\text { making;drudgery } \\
\text { reduction,etc) }\end{array}$ & & \\
\hline & $\begin{array}{l}\text { Dietary diversification and } \\
\text { Nutritional status of } \\
\text { population } \\
\end{array}$ & & \\
\hline & Livestock holding(herd size) & & \\
\hline & GDP(National) & & \\
\hline
\end{tabular}

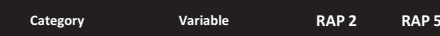

Technology

\begin{tabular}{|c|c|c|c|c|c|c|c|c|c|c|c|c|}
\hline & $\begin{array}{l}\text { No } \\
\text { change }\end{array}$ & $\begin{array}{l}\begin{array}{l}\text { Small } \\
\text { increase }\end{array}\end{array}$ & $\begin{array}{l}\text { Small to } \\
\text { Medium } \\
\text { increase }\end{array}$ & $\begin{array}{l}\text { Medium } \\
\text { Increase }\end{array}$ & $\begin{array}{l}\text { Medium } \\
\text { to large } \\
\text { increase }\end{array}$ & $\begin{array}{l}\text { Large } \\
\text { increase }\end{array}$ & $\begin{array}{l}\text { Small } \\
\text { decrease }\end{array}$ & $\begin{array}{l}\text { Small to } \\
\text { medium } \\
\text { decrease }\end{array}$ & $\begin{array}{l}\text { Medium } \\
\text { decrease }\end{array}$ & $\begin{array}{l}\text { Medium } \\
\text { to Large } \\
\text { decrease }\end{array}$ & $\begin{array}{l}\text { Large } \\
\text { increase }\end{array}$ & Disappear \\
\hline $\begin{array}{l}\text { Direction } \\
\text { and } \\
\text { magnitude }\end{array}$ & & & & & & & & & & & & $X$ \\
\hline
\end{tabular}


Nioro

Table A.9. Senegal, Nioro: Trend table for Green and Grey RAPs.

\begin{tabular}{|c|c|c|c|c|c|c|c|c|c|c|c|c|}
\hline \multicolumn{3}{|c|}{ Category } & \multicolumn{6}{|c|}{ Variables } & \multicolumn{2}{|c|}{ Green RAP } & Grey RAP & \\
\hline \multirow{4}{*}{\multicolumn{3}{|c|}{ Bio-physical }} & \multicolumn{6}{|c|}{ Herd size } & \multicolumn{2}{|l|}{$\longrightarrow$} & & \\
\hline & & & \multicolumn{6}{|c|}{ Livestock productivity } & \multicolumn{2}{|l|}{$\longrightarrow$} & & \\
\hline & & & \multicolumn{6}{|c|}{ Soil degradation } & \multicolumn{2}{|l|}{$\longrightarrow$} & & \\
\hline & & & \multicolumn{6}{|c|}{ Water availability and accessibility } & \multicolumn{2}{|l|}{$\longrightarrow$} & $\rightarrow$ & \\
\hline \multirow{6}{*}{\multicolumn{3}{|c|}{$\begin{array}{c}\text { Institutional/ } \\
\text { Policy }\end{array}$}} & \multicolumn{6}{|c|}{ Change in transportation infrastructure } & \multicolumn{2}{|l|}{$\longrightarrow$} & & \\
\hline & & & \multicolumn{6}{|c|}{ Fertilizer subsidies } & \multicolumn{2}{|l|}{$\longrightarrow$} & $\nabla$ & \\
\hline & & & \multicolumn{6}{|c|}{ Fertilizer prices } & \multicolumn{2}{|l|}{$\longrightarrow$} & $\Delta$ & \\
\hline & & & \multicolumn{6}{|c|}{ Fertilizer use } & \multicolumn{2}{|l|}{$\longrightarrow$} & & \\
\hline & & & \multicolumn{6}{|c|}{ Organic fertilizer (manure) } & \multicolumn{2}{|l|}{$\vec{P}$} & & \\
\hline & & & \multicolumn{6}{|c|}{ Community based organizations (CBOs) } & \multicolumn{2}{|l|}{$\longrightarrow$} & $\rightarrow$ & \\
\hline \multirow{7}{*}{\multicolumn{3}{|c|}{$\begin{array}{l}\text { Socio- } \\
\text { economic }\end{array}$}} & \multicolumn{6}{|c|}{ Human capital } & \multicolumn{2}{|l|}{$\gamma$} & & \\
\hline & & & \multicolumn{6}{|c|}{ Labor availability } & \multicolumn{2}{|l|}{$\longrightarrow$} & $\rightarrow$ & \\
\hline & & & \multicolumn{6}{|c|}{ Labor demand } & & & & \\
\hline & & & Labor wa & ge & & & & & & & & \\
\hline & & & Househo & Id size & & & & & & & $\rightarrow$ & \\
\hline & & & Farm siz & & & & & & & & $\rightarrow$ & \\
\hline & & & Non-agri & cultura & income & & & & & & 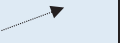 & \\
\hline & & & Informat & ion anc & Communic & cation $t$ & echnolc & gies & & & $\nabla$ & \\
\hline & & & Use of in & nprove & varieties & & & & & & & \\
\hline & & & Access t & energ & & & & & & & & \\
\hline & & & Mechani & zation & & & & & & & & \\
\hline lange & \begin{tabular}{|l|} 
Small \\
increase
\end{tabular} & \begin{tabular}{|c|} 
Smal \\
med
\end{tabular} & $\begin{array}{l}\text { II to } \\
\text { lium increase }\end{array}$ & $\begin{array}{l}\text { Medium } \\
\text { increase }\end{array}$ & $\begin{array}{l}\text { Medium to } \\
\text { large increase }\end{array}$ & \begin{tabular}{|l|} 
Large \\
increase
\end{tabular} & $\begin{array}{l}\text { Small } \\
\text { decrease }\end{array}$ & $\begin{array}{l}\text { Small t } \\
\text { mediur }\end{array}$ & decrease & $\begin{array}{l}\text { Medium } \\
\text { decrease }\end{array}$ & $\begin{array}{l}\text { Medium to } \\
\text { large decrease }\end{array}$ & \begin{tabular}{l|} 
Large \\
decrease
\end{tabular} \\
\hline$\rightarrow$ & $\longrightarrow$ & - & & $\longrightarrow$ & $\rightarrow$ & $\nearrow$ & $\longrightarrow$ & $\rightarrow$ & & 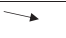 & $\triangle$ & $y$ \\
\hline
\end{tabular}

\section{Key Drivers and Their Quantification}

The socio-economic and policy drivers include fertilizer subsidy and prices, household characteristics such as household size, farm size, off-farm income, and livestock indicators. Under Green RAP, the $20 \%$ fertilizer subsidy results in slightly lower fertilizer prices and greater use. Household size and farm size decrease respectively, by $25 \%$ and $20 \%$ while non-agricultural income experiences an increase (20\%). Livestock productivity displays a $30 \%$ improvement when herd size decreases by $25 \%$. 
Table A.10. Senegal, Nioro: Selected drivers for Green RAP.

\begin{tabular}{|c|c|c|c|}
\hline Fertilizer prices & decrease & Small & $20 \%$ \\
\hline Fertilizer use & increase & $\begin{array}{l}\text { small to } \\
\text { medium }\end{array}$ & $\begin{array}{c}\text { maize: fertilizer use varies in three } \\
\text { subsamples: Fert=0 [10 kgN/ha]; } \\
0<\text { Fert } \leq 15 \text { [30 kgN/ha]; Fert }>15 \text { [40 } \\
\text { kgN/ha]; Millet: fertilizer use from } 0 \text { to } 15 \\
\text { kgN/ha }\end{array}$ \\
\hline Subsidies & increase & Small & $20 \%$ \\
\hline Household size & decrease & Moderate & $25 \%$ \\
\hline Farm size & decrease & Small & $20 \%$ \\
\hline Off farm income & increase & Medium & $20 \%$ \\
\hline Herd size & decrease & $\begin{array}{l}\text { small to } \\
\text { medium }\end{array}$ & $25 \%$ \\
\hline $\begin{array}{l}\text { Livestock } \\
\text { productivity }\end{array}$ & increase & Moderate & $30 \%$ \\
\hline
\end{tabular}

Table A.11. Senegal, Nioro: Selected drivers for Grey RAP.

\begin{tabular}{|c|c|c|c|}
\hline Fertilizer prices & Decrease & $\begin{array}{l}\text { medium to } \\
\text { large }\end{array}$ & $60 \%$ \\
\hline Fertilizer use & Increase & Large & $\begin{array}{c}\text { maize: fertilizer use varies in three } \\
\text { subsamples: Fert=0 [20 kgN/ha]; } \\
0<\text { Fert } \leq 15 \text { [30 kgN/ha]; Fert }>15 \text { [60 } \\
\text { kgN/ha]; millet: fertilizer use from } 0 \text { to } 15 \\
\text { kg/ha }\end{array}$ \\
\hline Subsidies & Increase & $\begin{array}{l}\text { medium to } \\
\text { large }\end{array}$ & $60 \%$ \\
\hline Household size & Decrease & Medium & $35 \%$ \\
\hline Farm size & decrease & Medium & $50 \%$ \\
\hline Off farm income & Increase & $\begin{array}{l}\text { medium to } \\
\text { large }\end{array}$ & $50 \%$ \\
\hline Herd size & Decrease & Medium & $30 \%$ \\
\hline $\begin{array}{l}\text { Livestock } \\
\text { productivity }\end{array}$ & Increase & $\begin{array}{l}\text { medium to } \\
\text { large }\end{array}$ & $40 \%$ \\
\hline
\end{tabular}

The socio-economic and policy drivers under Grey RAP display the same direction of change for most of the variables as shown in Green RAP. However, the magnitude is quite different. For instance, fertilizer subsidy is large at $60 \%$ resulting in larger fertilizer use, in accordance with Grey RAP orientation. Likewise, household size and farm size decrease by $35 \%$ and $50 \%$, respectively, while off-farm income records a $50 \%$ increase. Livestock productivity is up slightly at $40 \%$ and herd size decreases by $30 \%$. 


\section{Navrongo}

Table A.12. Ghana, Navrongo: Selected drivers for the Green and Grey RAPs.

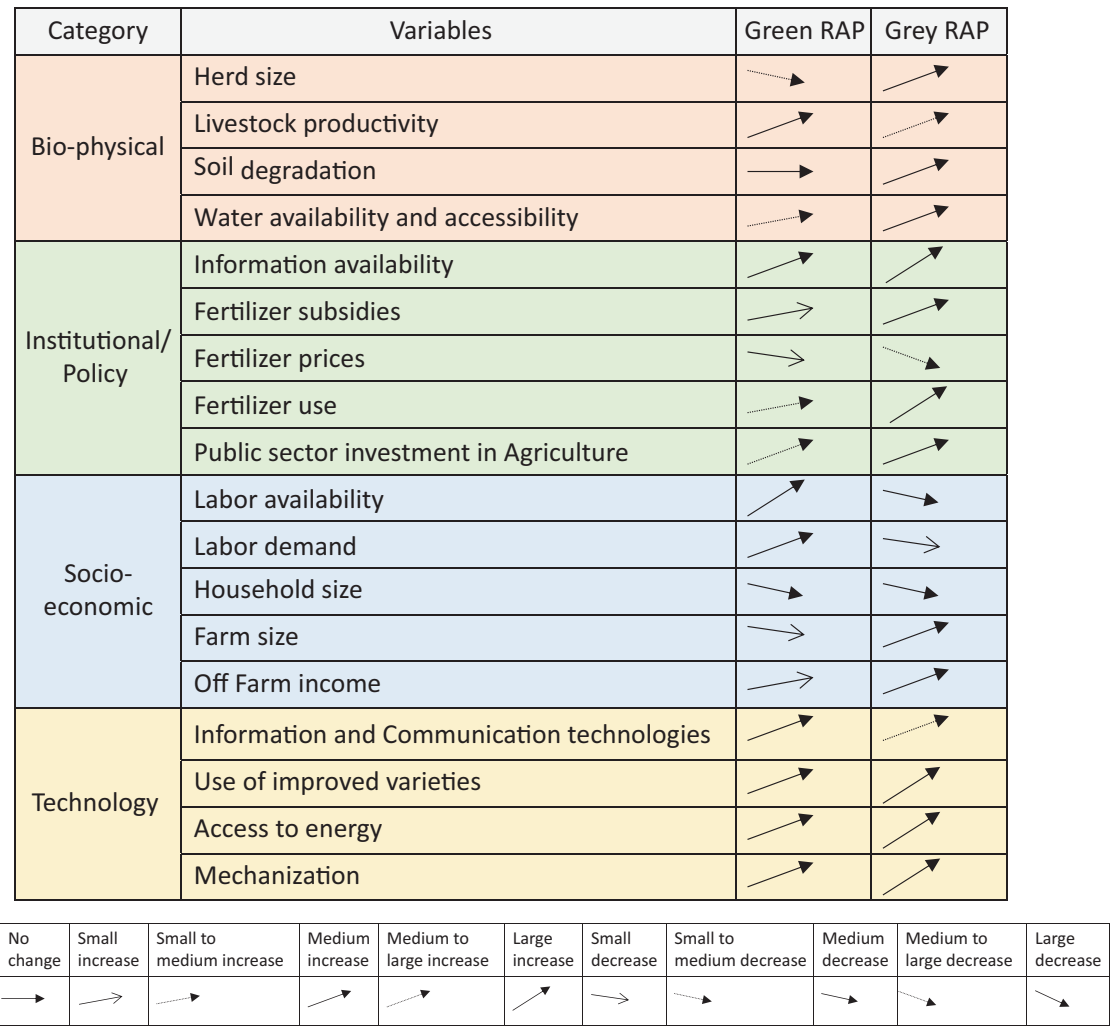


Table A.13. India, Indo-Gangetic Basin: Trend table for the BAU, Green and Grey RAPs.

\begin{tabular}{|c|c|c|c|}
\hline \multirow{2}{*}{ Variable } & \multicolumn{3}{|c|}{ Direction and Magnitude } \\
\hline & BAU & Green & Grey \\
\hline Soil degradation & $\longrightarrow$ & $\longrightarrow$ & $\longrightarrow$ \\
\hline Groundwater level & & $\longrightarrow$ & $\longrightarrow$ \\
\hline Input subsidies & $\longrightarrow$ & $\longrightarrow$ & \\
\hline Price support & & $\longrightarrow$ & $\longrightarrow$ \\
\hline Pest and disease & $\longrightarrow$ & $\longrightarrow$ & $\Longrightarrow$ \\
\hline Crop insurance & $\longrightarrow$ & & \\
\hline Farm size & $\longrightarrow$ & $\longrightarrow$ & $\rightarrow$ \\
\hline Cost of production & & $\longrightarrow$ & $\longrightarrow$ \\
\hline Labor availability & $\longrightarrow$ & $\longrightarrow$ & $\longrightarrow$ \\
\hline Household size & $\longrightarrow$ & & \\
\hline Herd size & $\longrightarrow$ & $\rightarrow$ & \\
\hline Non-farm income & $\longrightarrow$ & $\longrightarrow$ & \\
\hline Improved variety (adoption) & $\longrightarrow$ & $\longrightarrow$ & \\
\hline
\end{tabular}

\section{Legend:}

\begin{tabular}{|l|l|l|l|l|l|l|l|l|l|l|l|}
\hline & $\begin{array}{l}\text { No } \\
\text { change }\end{array}$ & $\begin{array}{l}\text { Small } \\
\text { increase }\end{array}$ & $\begin{array}{l}\text { Small to } \\
\text { medium } \\
\text { increase }\end{array}$ & $\begin{array}{l}\text { Medium } \\
\text { increase }\end{array}$ & $\begin{array}{l}\text { Medium } \\
\text { to large } \\
\text { increase }\end{array}$ & $\begin{array}{l}\text { Large } \\
\text { increase }\end{array}$ & $\begin{array}{l}\text { Small } \\
\text { decrease }\end{array}$ & $\begin{array}{l}\text { Small to } \\
\text { medium } \\
\text { decrease }\end{array}$ & $\begin{array}{l}\text { Medium } \\
\text { decrease }\end{array}$ & $\begin{array}{l}\text { Medium } \\
\text { to large } \\
\text { decrease }\end{array}$ & $\begin{array}{l}\text { Large } \\
\text { decrease }\end{array}$ \\
\hline $\begin{array}{l}\text { Direction \& } \\
\text { magnitude }\end{array}$ & $\longrightarrow$ & $\longrightarrow$ & $\longrightarrow$ & & & $>$ & $\rightarrow$ & &
\end{tabular}


Table A.14. India, Tamil Nadu (South India): Drivers for Green RAP.

\begin{tabular}{|c|c|c|c|c|c|c|}
\hline Variable & $\begin{array}{l}\text { Direction of } \\
\text { change }\end{array}$ & $\begin{array}{l}\text { Magnitude of } \\
\text { change }\end{array}$ & $\begin{array}{l}\text { Quantum of } \\
\text { change }\end{array}$ & $\begin{array}{l}\text { Rationale for } \\
\text { change }\end{array}$ & Agreement & Confidence \\
\hline \multicolumn{7}{|l|}{ A. Bio-Physical variables } \\
\hline Ground water table & Increase & Small & $10 \%$ & Construction of water harvesting structures & High & High \\
\hline Availability of surface water & Increase & Small & $5 \%$ & Expected Increase in rainfall & Medium & Medium \\
\hline Water quality & Decrease & Small & $10 \%$ & Pollution & Medium & High \\
\hline Water Use Efficiency & Increase & Small & $30 \%$ & More towards Drip irrigation & High & High \\
\hline Forest cover & Increase & Small & $10 \%$ & $\begin{array}{l}\text { More social forestry and awareness among the } \\
\text { community }\end{array}$ & High & High \\
\hline Soil health & Increase & Small & $10 \%$ & Integrated nutrient management & Medium & Low \\
\hline Livestock population & No change & - & - & $\begin{array}{l}\text { Demand for livestock products will increase but due to } \\
\text { problem of maintenance the size will remain the } \\
\text { same. }\end{array}$ & Medium & Low \\
\hline Pest and disease problem & Increase & Medium & $20 \%$ & $\begin{array}{l}\text { Minor pest will become major and would create } \\
\text { problem }\end{array}$ & High & High \\
\hline Weed dominance & Increase & Medium & $15 \%$ & $\begin{array}{l}\text { Change in temperature and precipitation would favor } \\
\text { weed sp. }\end{array}$ & Medium & Medium \\
\hline \multicolumn{7}{|l|}{ B. Technology variables } \\
\hline Improved crop varieties & Increase & High & $40 \%$ & $\begin{array}{l}\text { More cultivars will be developed for biotic and abiotic } \\
\text { stresses }\end{array}$ & High & High \\
\hline Crop productivity & Increase & High & $40 \%$ & $\begin{array}{l}\text { More adoption of improved technologies and high } \\
\text { yielding cultivars }\end{array}$ & High & High \\
\hline Alternative crops & Increase & Low & $10 \%$ & $\begin{array}{l}\text { Non-conventional crops will be promoted Eg: } \\
\text { Nutri-cereals }\end{array}$ & Medium & Medium \\
\hline Cropping intensity & Increase & Medium & $20 \%$ & $\begin{array}{l}\text { Farmers will accommodate short duration cultivars to } \\
\text { increase the cropping intensity }\end{array}$ & Medium & High \\
\hline Nutrient Use Efficiency & Increase & High & $40 \%$ & $\begin{array}{l}\text { Nutrients will be given through fertigation in multiple } \\
\text { topdressing }\end{array}$ & High & High \\
\hline Post Harvest Losses & Decrease & Medium & $30 \%$ & $\begin{array}{l}\text { Value added products will be developed. } \\
\text { More storage facilities will be created }\end{array}$ & Medium & Medium \\
\hline Energy Use Efficiency & Increase & Medium & $30 \%$ & $\begin{array}{l}\text { Non-conventional energy sources like wind energy } \\
\text { and solar energy will be tapped to a maximum }\end{array}$ & High & Medium \\
\hline
\end{tabular}


Table A.14. (Continued)

\begin{tabular}{|c|c|c|c|c|c|c|}
\hline Variable & $\begin{array}{l}\text { Direction of } \\
\text { change }\end{array}$ & $\begin{array}{l}\text { Magnitude of } \\
\text { change }\end{array}$ & $\begin{array}{l}\text { Quantum of } \\
\text { change }\end{array}$ & $\begin{array}{l}\text { Rationale for } \\
\text { change }\end{array}$ & Agreement & Confidence \\
\hline Farm mechanization & Increase & Medium & $25 \%$ & $\begin{array}{l}\text { Labor available for crop production will get declined. } \\
\text { More custom hiring centres will be created to } \\
\text { increase the timely availability of machineries at } \\
\text { reasonable rental values }\end{array}$ & High & High \\
\hline $\begin{array}{l}\text { Information and } \\
\text { communication technology } \\
\text { C. Socio economic variables }\end{array}$ & Increase & High & $50 \%$ & $\begin{array}{l}\text { Mobile phone and satellite communication technology } \\
\text { will increase the reach of unreached }\end{array}$ & High & High \\
\hline Size of farm holding & Decrease & Medium & $50 \%$ & Fragmentation of holding & High & High \\
\hline Off-farm income & Increase & Medium & $20 \%$ & More avenues for farm associated activities & Medium & Medium \\
\hline Income inequality & Increase & High & $30 \%$ & High input cost, High wage rate & Medium & Medium \\
\hline Wage rate for the labors & Increase & High & $40 \%$ & Low labor available for agriculture & High & High \\
\hline Literacy level & Increase & High & $40 \%$ & More awareness on the importance of education & High & High \\
\hline Dietary changes & Increase & Medium & $20 \%$ & More calorific food & Medium & Medium \\
\hline \multicolumn{7}{|l|}{ D. Policy related variables } \\
\hline Fertilizer subsidy & Decrease & Medium & $20 \%$ & $\begin{array}{l}\text { Government would promote integrated nutrient } \\
\text { management }\end{array}$ & High & Medium \\
\hline Fertilizer price & Increase & Medium & $30 \%$ & Subsidy will be withdrawn & High & High \\
\hline Subsidy to Organic manure & Increase & Medium & $20 \%$ & To promote organic farming & High & Medium \\
\hline $\begin{array}{l}\text { Support to Farmer producer } \\
\text { organizations }\end{array}$ & Increase & High & $25 \%$ & $\begin{array}{l}\text { To stabilize the farmers income and to improve the } \\
\text { livelihood of the farming community }\end{array}$ & Medium & Low \\
\hline Minimum support price & Increase & Medium & $20 \%$ & To encourage the farmers in growing the crops & Medium & Medium \\
\hline Subsidy for micro irrigation & Increase & High & $25 \%$ & To enhance the area under irrigation & High & High \\
\hline Access to Credit facilities & Increase & High & $20 \%$ & More awareness will be created & Medium & Medium \\
\hline Access to value chains & Increase & High & $15 \%$ & To increase the income of the farmers & Medium & Medium \\
\hline Market infrastructure & Increase & Medium & $10 \%$ & To reduce the post harvest losses & Medium & Medium \\
\hline Crop insurance coverage & Increase & High & $40 \%$ & More frequent occurrence of extreme weather events & High & High \\
\hline Electricity subsidy & Decrease & Medium & $30 \%$ & More demand for electricity & High & High \\
\hline
\end{tabular}


Table A.15. India, Tamil Nadu (South India): Drivers for Grey RAP.

\begin{tabular}{|c|c|c|c|c|c|c|}
\hline $\begin{array}{l}\text { Variable } \\
\text { A. Bio-Physical variables }\end{array}$ & $\begin{array}{l}\text { Direction of } \\
\text { change }\end{array}$ & $\begin{array}{l}\text { Magnitude of } \\
\text { change }\end{array}$ & $\begin{array}{l}\text { Quantum of } \\
\text { change }\end{array}$ & $\begin{array}{l}\text { Rationale for } \\
\text { change }\end{array}$ & Agreement & Confidence \\
\hline Ground water table & Decrease & Medium & $20 \%$ & Over exploitation of ground water & High & High \\
\hline Availability of surface water & Decrease & Small & $10 \%$ & $\begin{array}{l}\text { Interstate conflict will decrease the water flow in the } \\
\text { rivers }\end{array}$ & High & High \\
\hline Water quality & Decrease & Small & $10 \%$ & Pollution & Medium & High \\
\hline Water Use Efficiency & Decrease & Medium & $20 \%$ & Enhanced evapotranspiration & High & High \\
\hline Forest cover & No change & - & - & $\begin{array}{l}\text { Major initiatives to increase the forest cover will not } \\
\text { be carried out }\end{array}$ & High & High \\
\hline Soil health & Decrease & Medium & $20 \%$ & Mostly chemical fertilizers will be used in the future & Medium & High \\
\hline Livestock population & Decrease & Medium & $20 \%$ & Low feed availability & Medium & Low \\
\hline Pest and disease problem & Increase & High & $30 \%$ & $\begin{array}{l}\text { Minor pest will become major and would create } \\
\text { problem. } \\
\text { Pests will develop resistance against the prevailing } \\
\text { pesticide molecules }\end{array}$ & High & High \\
\hline Weed dominance & Increase & Medium & $20 \%$ & $\begin{array}{l}\text { Change in temperature and precipitation would favor } \\
\text { weed sp. }\end{array}$ & Medium & Medium \\
\hline \multicolumn{7}{|l|}{ B. Technology variables } \\
\hline Improved crop varieties & Increase & Medium & $20 \%$ & $\begin{array}{l}\text { More cultivars will be developed for biotic and abiotic } \\
\text { stresses }\end{array}$ & High & High \\
\hline Crop productivity & Increase & High & $40 \%$ & $\begin{array}{l}\text { More adoption of improved technologies and high } \\
\text { yielding cultivars }\end{array}$ & High & High \\
\hline Alternative crops & Increase & Low & $5 \%$ & $\begin{array}{l}\text { Non-conventional crops will be promoted Eg: } \\
\text { Nutri-cereals }\end{array}$ & Medium & Medium \\
\hline Cropping intensity & Increase & Low & $10 \%$ & $\begin{array}{l}\text { Farmers will accommodate short duration cultivars to } \\
\text { increase the cropping intensity }\end{array}$ & Medium & High \\
\hline Nutrient Use Efficiency & Decrease & High & $30 \%$ & Over use of Chemical fertilizers & High & High \\
\hline Post Harvest Losses & Increase & High & $50 \%$ & More extreme weather events & Medium & Medium \\
\hline Energy Use Efficiency & Decrease & Medium & $30 \%$ & Energy from fossil fuel source & High & High \\
\hline
\end{tabular}


Table A.15. (Continued)

\begin{tabular}{|c|c|c|c|c|c|c|}
\hline Variable & $\begin{array}{l}\text { Direction of } \\
\text { change }\end{array}$ & $\begin{array}{l}\text { Magnitude of } \\
\text { change }\end{array}$ & $\begin{array}{c}\text { Quantum of } \\
\text { change }\end{array}$ & $\begin{array}{c}\text { Rationale for } \\
\text { change }\end{array}$ & Agreement & Confidence \\
\hline Farm mechanization & Increase & Medium & $25 \%$ & $\begin{array}{l}\text { Labor available for crop production will get declined. } \\
\text { More custom hiring centres will be created to } \\
\text { increase the timely availability of machineries at } \\
\text { reasonable rental values }\end{array}$ & High & High \\
\hline $\begin{array}{l}\text { Information and } \\
\text { communication technology } \\
\text { C. Socio economic variables }\end{array}$ & Increase & High & $50 \%$ & $\begin{array}{l}\text { Mobile phone and satellite communication technology } \\
\text { will increase the reach of unreached }\end{array}$ & High & High \\
\hline Size of farm holding & Decrease & Medium & $50 \%$ & Fragmentation of holding & High & High \\
\hline Off-farm income & Increase & Medium & $20 \%$ & More avenues for farm associated activities & Medium & Medium \\
\hline Income inequality & Increase & High & $40 \%$ & High input cost, High wage rate & Medium & Medium \\
\hline Wage rate for the labors & Increase & High & $40 \%$ & Low labor available for agriculture & High & High \\
\hline Literacy level & Increase & High & $40 \%$ & More awareness on the importance of education & High & High \\
\hline Dietary changes & Increase & Medium & $40 \%$ & More nonvegetarian food consumption & Medium & Medium \\
\hline $\begin{array}{l}\text { D. Policy related variables } \\
\text { Fertilizer subsidy }\end{array}$ & Decrease & High & $40 \%$ & $\begin{array}{l}\text { Government would promote integrated nutrient } \\
\text { management }\end{array}$ & High & Medium \\
\hline Fertilizer price & Increase & High & $40 \%$ & Subsidy will be withdrawn & High & High \\
\hline Subsidy to Organic manure & decrease & Medium & $20 \%$ & $\begin{array}{l}\text { Only chemical farming - no concern about the } \\
\text { environment }\end{array}$ & High & Medium \\
\hline $\begin{array}{l}\text { Support to Farmer producer } \\
\text { organizations }\end{array}$ & Increase & Low & $5 \%$ & $\begin{array}{l}\text { To stabilize the farmers income and to improve the } \\
\text { livelihood of the farming community }\end{array}$ & Medium & Low \\
\hline Minimum support price & Increase & Medium & $20 \%$ & To encourage the farmers in growing the crops & Medium & Medium \\
\hline Subsidy for micro irrigation & Increase & Low & $5 \%$ & To enhance the area under irrigation & High & High \\
\hline Access to Credit facilities & Increase & High & $20 \%$ & More awareness will be created & Medium & Medium \\
\hline Access to value chains & Increase & High & $15 \%$ & To increase the income of the farmers & Medium & Medium \\
\hline Market infrastructure & Increase & Medium & $10 \%$ & To reduce the post harvest losses & Medium & Medium \\
\hline Crop insurance coverage & Increase & High & $40 \%$ & More frequent occurrence of extreme weather events & High & High \\
\hline Electricity subsidy & Decrease & High & $50 \%$ & More demand for electricity & High & High \\
\hline
\end{tabular}


Table A.16. Zimbabwe, Nioro: Drivers and storylines for 3 Representative Agricultural Pathways.

\begin{tabular}{|c|c|c|c|c|c|}
\hline & Busin & ss-as-usual (RAP 2) & Sustain & bility (RAP4) & Fast-economic Growth (RAP5) \\
\hline Cultivated land & $\longrightarrow$ & $\begin{array}{l}\text { Intensified crop and fodder } \\
\text { production on less land }\end{array}$ & & $\begin{array}{l}\text { Full use of on-farm uncultivated land and } \\
\text { expansion of land, following labor saving } \\
\text { technologies and improved access to } \\
\text { markets }\end{array}$ & $\begin{array}{l}\text { Expansion of land for those with } \\
\text { more resources, the poor remain } \\
\text { with very small plots }\end{array}$ \\
\hline $\begin{array}{l}\text { Legume } \\
\text { cultivation }\end{array}$ & $\longrightarrow$ & $\begin{array}{l}\text { Small expansion of the } \\
\text { cultivated area with legumes }\end{array}$ & & $\begin{array}{l}\text { Massive expansion, supporting } \\
\text { integrated soil fertility management, with } \\
\text { access to high yielding varieties and } \\
\text { mechanized processing }\end{array}$ & $\begin{array}{l}\text { Focus on maize as cash crop, along } \\
\text { with inorganic fertilizer to } \\
\text { maintain production levels }\end{array}$ \\
\hline Herd size & $\longrightarrow$ & $\begin{array}{l}\text { Small increases in herd sizes } \\
\text { through improved feed } \\
\text { management and animal } \\
\text { husbandry }\end{array}$ & & $\begin{array}{l}\text { Larger herd sizes through greater on-farm } \\
\text { quality feed biomass production and } \\
\text { following market incentives; the poorest } \\
\text { also increase livestock production }\end{array}$ & $\begin{array}{l}\text { Larger herd sizes relying on } \\
\text { commercial stockfeed and } \\
\text { following market incentives; the } \\
\text { poorest remain without substantial } \\
\text { livestock assets }\end{array}$ \\
\hline Input use & $\longrightarrow$ & $\begin{array}{l}\text { Small increases in use of } \\
\text { fertilizer and improved seed } \\
\text { primarily for maize }\end{array}$ & & $\begin{array}{l}\text { Increased use of fertilizer and improved } \\
\text { seed for all crops; better feed from crop } \\
\text { residues and feed concentrates }\end{array}$ & $\begin{array}{l}\text { Massive increases in the use of } \\
\text { fertilizer and improved seed for all } \\
\text { crops, feed concentrates }\end{array}$ \\
\hline Family size & $\longrightarrow$ & $\begin{array}{l}\text { Small reduction in farm labor } \\
\text { as off-farm income options are } \\
\text { limited }\end{array}$ & & $\begin{array}{l}\text { Small reduction in farm labor as off-farm } \\
\text { income options are limited }\end{array}$ & $\begin{array}{l}\text { More off-farm opportunities } \\
\text { reduce family sizes }\end{array}$ \\
\hline Off-farm income & $\longrightarrow$ & $\begin{array}{l}\text { Limited growth in other sectors } \\
\text { attract people, people rely on } \\
\text { agriculture }\end{array}$ & & $\begin{array}{l}\text { Slow growth in other sectors attract } \\
\text { people, income diversification }\end{array}$ & $\begin{array}{l}\text { Opportunities in agri-business } \\
\text { adsorb particularly the very poor as } \\
\text { farm labor }\end{array}$ \\
\hline Nutrition & $\longrightarrow$ & $\begin{array}{l}\text { Limited improvement to } \\
\text { nutritious food supply }\end{array}$ & & $\begin{array}{l}\text { Strong emphasis on health, better access } \\
\text { to diverse food through farm } \\
\text { diversification }\end{array}$ & $\begin{array}{l}\text { Greater food availability through } \\
\text { increased production }\end{array}$ \\
\hline $\begin{array}{l}\text { Women } \\
\text { empowerment }\end{array}$ & $\longrightarrow$ & $\begin{array}{l}\text { Natural process as men work } \\
\text { off-farm }\end{array}$ & & $\begin{array}{l}\text { Strong emphasis on gender equity in } \\
\text { production and marketing, with a link to } \\
\text { farm diversification and nutrition }\end{array}$ & $\begin{array}{l}\text { Ignorance of social and health } \\
\text { development }\end{array}$ \\
\hline
\end{tabular}

Note: $\nearrow$ = Medium increase; $\longrightarrow$ = small increase; $\longrightarrow=$ medium decrease; $\longrightarrow$ small decrease; $\longrightarrow=$ no change.

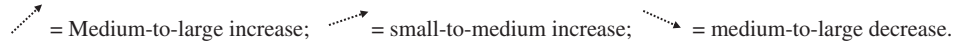

Table A.17. Exogenous productivity and producer price trends $(1=$ no change), projected for agricultural outputs mid-century under 3 RAPs at national level, under high and low price assumptions, without and with climate change, used to quantifity model parameters (source: IMPACT).

\begin{tabular}{|c|c|c|c|c|c|c|c|c|c|c|c|c|c|c|c|}
\hline & \multicolumn{5}{|c|}{ Business-as-usual (RAP-2) } & \multicolumn{5}{|c|}{ Sustainability (RAP4) } & \multicolumn{5}{|c|}{ Fast-economic growth (RAP5) } \\
\hline & \multirow{2}{*}{$\begin{array}{l}\text { Produc- } \\
\text { tivity }\end{array}$} & \multicolumn{2}{|c|}{ High price } & \multicolumn{2}{|c|}{ Low price } & \multirow{2}{*}{$\begin{array}{l}\text { Produc- } \\
\text { tivity }\end{array}$} & \multicolumn{2}{|c|}{ High price } & \multicolumn{2}{|c|}{ Low price } & \multirow{2}{*}{$\begin{array}{l}\text { Produc- } \\
\text { tivity }\end{array}$} & \multicolumn{2}{|c|}{ High price } & \multicolumn{2}{|c|}{ Low price } \\
\hline & & $\begin{array}{l}\text { No } \\
\text { CC }\end{array}$ & $\begin{array}{l}\text { With } \\
\text { CC }\end{array}$ & $\begin{array}{l}\text { No } \\
\text { CC }\end{array}$ & $\begin{array}{l}\text { With } \\
\text { CC }\end{array}$ & & $\begin{array}{l}\text { No } \\
\text { CC }\end{array}$ & $\begin{array}{l}\text { With } \\
\text { CC }\end{array}$ & $\begin{array}{l}\text { No } \\
\text { CC }\end{array}$ & $\begin{array}{l}\text { With } \\
\text { CC }\end{array}$ & & $\begin{array}{l}\text { No } \\
\text { CC }\end{array}$ & $\begin{array}{l}\text { With } \\
\text { CC }\end{array}$ & $\begin{array}{l}\text { No } \\
\text { CC }\end{array}$ & $\begin{array}{l}\text { With } \\
\text { CC }\end{array}$ \\
\hline Maize & 1.4 & 1 & 1.1 & 1 & 1.1 & 2.1 & 1.5 & 1.6 & 1 & 1.1 & 1.7 & 1.4 & 1.6 & 1 & 1.1 \\
\hline Sorghum & 1.35 & 1 & 1.1 & 1 & 1.1 & 2.4 & 1.4 & 1.6 & 1 & 1.2 & 2 & 1.5 & 1.8 & 1 & 1.2 \\
\hline Groundnut & 1.35 & 1 & 1.1 & 1 & 1.1 & 1.7 & 1.7 & 1.8 & 1 & 1.1 & 1.5 & 1.7 & 1.8 & 1 & 1.1 \\
\hline Beef & 1.3 & 1 & 1.15 & 1 & 1.15 & 2.1 & 1.4 & 1.4 & 1 & 1.1 & 1.7 & 1.2 & 1.2 & 1 & 1.1 \\
\hline Goat meat & 1.25 & 1 & 1.1 & 1 & 1.1 & 1.6 & 1.4 & 1.5 & 1 & 1.1 & 1.3 & 1.2 & 1.5 & 1 & 1.1 \\
\hline Milk & 1.1 & & 1.05 & & & 1.2 & 1.2 & 1.2 & 1 & 1.1 & 1.1 & 1.2 & 1.1 & 1 & 1.1 \\
\hline
\end{tabular}

\section{References}

Antle, John, Roberto O. Valdivia et al. 2015. AgMIP's Trans-disciplinary Approach to Regional Integrated Assessment of Climate Impact, Vulnerability and Adaptation of Agricultural Systems. In C. Rosenzweig and D. Hillel (eds.), Handbook of Climate Change and Agroecosystems: The Agricultural Model Intercomparison and Improvement Project (AgMIP). ICP Series on Climate Change Impacts, Adaptation, and Mitigation, Vol. 3. Imperial College Press, doi:10.1142/9781783265640_0002.

ICRISAT. 2016. Building Climate-Smart Villages: Five approaches for helping farmers adapt to climate change. 2016. International Crops Research Institute for the Semi-Arid Tropics. Patancheru 502 324, Telangana, India: 28 pp.

Mitter, H., Techen, A.-K. et al. 2019. A protocol to develop Shared Socio-economic Pathways for European agriculture. Journal of Environmental Management, 252: 109701. https://doi.org/10. 1016/j.jenvman.2019.109701

Mitter, H., Techen, A.-K. et al. 2020. Shared Socio-economic Pathways for European agriculture and food systems: The Eur-Agri-SSPs. Global Environmental Change, in press. 
O'Neill, B.C., Kriegler, E. et al. 2014. A new scenario framework for climate change research: The concept of shared socioeconomic pathways. Climatic Change, 122: 387-400. https://doi.org/ 10.1007/s10584-013-0905-2

O'Neill, B.C., Kriegler, E. et al. 2017. The roads ahead: Narratives for shared socioeconomic pathways describing world futures in the 21st century. Global Environmental Change, 42: 169-180. https://doi.org/10.1016/j.gloenvcha.2015.01.004

Valdivia, Roberto O., John M. Antle et al. 2015. Representative Agricultural Pathways and Scenarios for Regional Integrated Assessment of Climate Change Impact, Vulnerability and Adaptation. In C. Rosenzweig and D. Hillel (eds.), Handbook of Climate Change and Agroecosystems: The Agricultural Model Intercomparison and Improvement Project (AgMIP). ICP Series on Climate Change Impacts, Adaptation, and Mitigation, Vol. 3. Imperial College Press, pp. 101156, doi:10.1142/9781783265640_0005.

Valdivia, R. and Antle, J. 2016. AgMIP Economic Model Scenario Design and Adaptation Analysis for Regional Research Teams, Phase 2 Protocols. AgMIP, www.agmip.org

Valdivia, R., Antle, J. et al. 2019. Enhancing Agricultural Production and Food Security amid a Changing Climate: A New Approach to Inform Decision-Making. The Inter-American Institute for Cooperation on Agriculture - Climate Change, Natural Resources and Management of Production Risks and the Agricultural Model Intercomparison and Improvement Project. A Policy Brief presented at the Joint Inter-American Agricultural Ministers Exchange. Pre-COP 25. San José, Costa Rica.

Wiebe, K., Lotze-Campen, H. et al. 2015. Climate change impacts on agriculture in 2050 under a range of plausible socioeconomic and emissions scenarios. Environmental Research Letters, 10(8): 085010. https://doi.org/10.1088/1748-9326/10/8/085010 